NATIONAL LABORATORY

\title{
Preliminary Feasibility Assessment of Geologic Carbon Sequestration Potential for TVA's John Sevier and Kingston Power Plants
}

\section{March 2008}

\author{
Prepared by \\ Ellen D. Smith \\ James W. Saulsbury

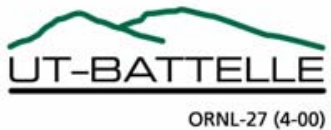




\title{
DOCUMENT AVAILABILITY
}

Reports produced after January 1, 1996, are generally available free via the U.S. Department of Energy (DOE) Information Bridge.

Web site http://www.osti.gov/bridge

Reports produced before January 1, 1996, may be purchased by members of the public from the following source.

\author{
National Technical Information Service \\ 5285 Port Royal Road \\ Springfield, VA 22161 \\ Telephone 703-605-6000 (1-800-553-6847) \\ TDD 703-487-4639 \\ Fax 703-605-6900 \\ E-mail info@ntis.gov \\ Web site http://www.ntis.gov/support/ordernowabout.htm
}

Reports are available to DOE employees, DOE contractors, Energy Technology Data Exchange (ETDE) representatives, and International Nuclear Information System (INIS) representatives from the following source.

Office of Scientific and Technical Information

P.O. Box 62

Oak Ridge, TN 37831

Telephone 865-576-8401

Fax 865-576-5728

E-mail reports@osti.gov

Web site http://www.osti.gov/contact.html

This report was prepared as an account of work sponsored by an agency of the United States Government. Neither the United States Government nor any agency thereof, nor any of their employees, makes any warranty, express or implied, or assumes any legal liability or responsibility for the accuracy, completeness, or usefulness of any information, apparatus, product, or process disclosed, or represents that its use would not infringe privately owned rights. Reference herein to any specific commercial product, process, or service by trade name, trademark, manufacturer, or otherwise, does not necessarily constitute or imply its endorsement, recommendation, or favoring by the United States Government or any agency thereof. The views and opinions of authors expressed herein do not necessarily state or reflect those of the United States Government or any agency thereof. 


\title{
PRELIMINARY FEASIBILITY ASSESSMENT OF GEOLOGIC CARBON SEQUESTRATION POTENTIAL FOR TVA'S JOHN SEVIER AND KINGSTON POWER PLANTS
}

\author{
Ellen D. Smith \\ James W. Saulsbury \\ Environmental Sciences Division \\ Oak Ridge National Laboratory
}

Date Published: March 2008

\author{
Prepared by \\ OAK RIDGE NATIONAL LABORATORY \\ Oak Ridge, Tennessee 37831-6283 \\ managed by \\ UT-BATTELLE, LLC \\ for the \\ U.S. DEPARTMENT OF ENERGY \\ under contract DE-AC05-00OR22725
}


[Blank page—do not page number blank backup pages] 


\section{CONTENTS}

Page

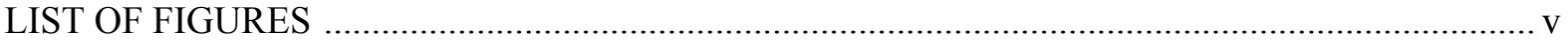

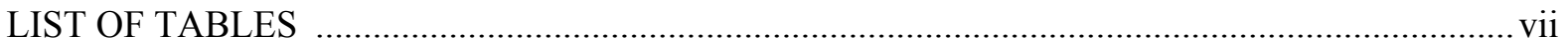

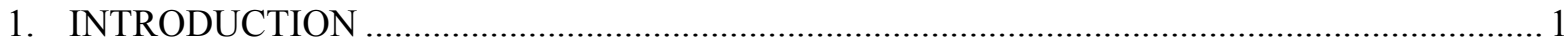

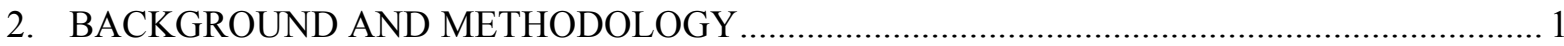

2.1 EXISTING ANALYSIS OF SEQUESTRATION POTENTIAL IN THE TVA

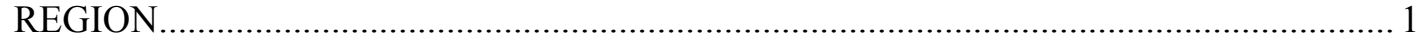

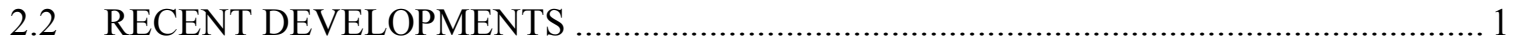

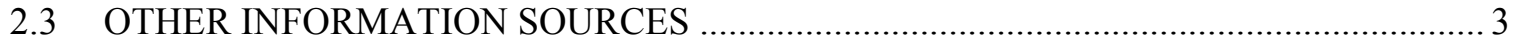

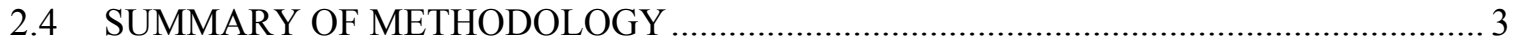

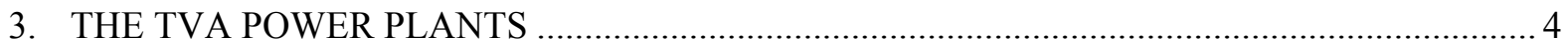

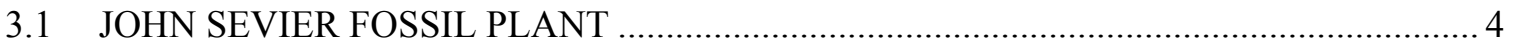

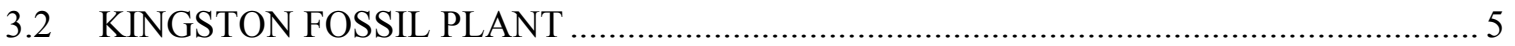

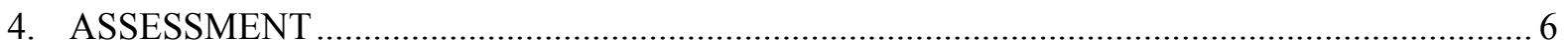

4.1 GEOLOGIC SUITABILITY FOR CARBON SEQUESTRATION .................................. 6

4.1.1 NETL Carbon Sequestration Program Findings ................................................... 7

4.1.2 Potential for Sequestration in Coal Seams .............................................................. 7

4.1.3 Potential for Sequestration in Deep Saline Formations ..................................... 11

4.1.3.1 Potential Reservoirs Identified by Regional Screening Studies ............... 11

4.1.3.2 Basal Sandstone Unit in Tennessee......................................................... 13

4.1.3.3 Knox Group in Eastern Kentucky and West Virginia............................. 16

4.2 ECONOMIC COSTS OF CARBON SEQUESTRATION ............................................... 19

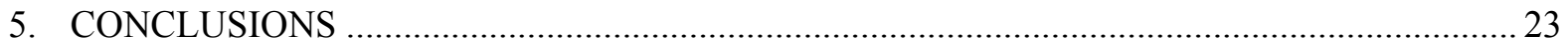

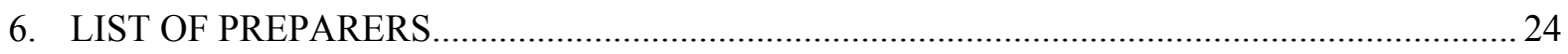

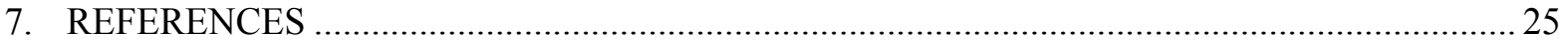


[Blank page—do not page number blank backup pages] 


\section{LIST OF FIGURES}

Figure

Page

1 General location map of the John Sevier and Kingston power plants within the TVA service region 4

Annual $\mathrm{CO}_{2}$ emissions from the John Sevier power plant 5

Annual $\mathrm{CO}_{2}$ emissions from the Kingston power plant

Locations of coal resources within approximately 200 miles of TVA's John Sevier and Kingston power plants 8 Locations of named coal basins in the Appalachian Basin relative to 200-mile distances from TVA's John Sevier and Kingston power plants Locations of oil, gas, and coal bed methane (CBM) wells in the Pocahontas Basin in southwestern Virginia.

In-place methane gas content in coal seams in a portion of the Pocahontas Basin, Virginia, Kentucky, and West Virginia

Total coal thickness in the Lee and Pocahontas Formations in a portion of the Pocahontas Basin, southwestern Virginia

Saline formations in Tennessee and other states identified by SECARB as having sequestration potential

Saline sandstone formations in Kentucky and other states identified by MRCSP as having sequestration potential.

Areas where TBEG identified high-potential geologic sinks in the vicinity of the Carolinas

Depth in meters to the base of the basal sandstone in middle Tennessee Geologic map of Tennessee with approximate locations of the John Sevier and Kingston power plants and arcs indicating 200-mile distances from the plants

Potential Knox Group geologic sink in eastern Kentucky, southern West Virginia, and southwestern Virginia as identified by Smyth et al. 2007: (a) depth to top of Knox Group and (b) Knox Group thickness 
[Blank page—do not page number blank backup pages] 


\section{LIST OF TABLES}

Table

Page

$1 \quad$ Annual $\mathrm{CO}_{2}$ emissions from the John Sevier power plant ........................................... 4

2 Annual $\mathrm{CO}_{2}$ emissions from the Kingston power plant ...............................................5

3 Estimated transportation, storage, and monitoring and verification costs for

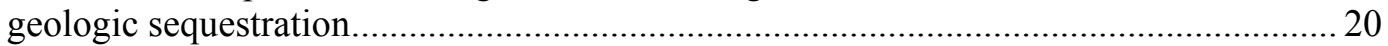

$4 \quad$ Estimated annual transportation, storage, and monitoring and verification costs for geologic sequestration for the John Sevier power plant .............................................. 21

5 Estimated annual transportation, storage, and monitoring and verification costs for geologic sequestration for the Kingston power plant....................................................... 21

6 Estimated total costs for $\mathrm{CO}_{2}$ capture and geologic sequestration at a pulverized

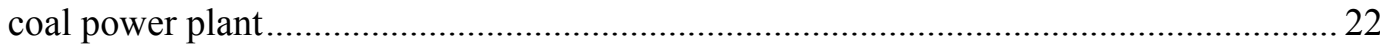


[Blank page—do not page number blank backup pages] 


\section{INTRODUCTION}

This is a preliminary assessment of the potential for geologic carbon sequestration for the Tennessee Valley Authority's (TVA) John Sevier and Kingston power plants. The purpose of this assessment is to make a "first cut" determination of whether there is sufficient potential for geologic carbon sequestration within 200 miles of the plants for TVA and Oak Ridge National Laboratory (ORNL) to proceed with a joint proposal for a larger project with a strong carbon management element. This assessment does not consider alternative technologies for carbon capture, but assumes the existence of a segregated $\mathrm{CO}_{2}$ stream suitable for sequestration.

\section{BACKGROUND AND METHODOLOGY}

\subsection{EXISTING ANALYSIS OF SEQUESTRATION POTENTIAL IN THE TVA REGION}

ORNL prepared a report on the on-site geologic sequestration potential for TVA's 11 fossil fuel power plants in 2002 (Tsouris et al. 2002). The objectives of that report were to review various methods reported in the literature for the separation and geologic sequestration of $\mathrm{CO}_{2}$ and evaluate the potential of TVA fossil fuel plants for on-site geologic sequestration. Because the analysis assumed that sequestration would need to occur within close proximity of the power plant, the assessment of sequestration potential was restricted to the actual site locations. Of the 11 plants evaluated, the two plants that were given the highest priority for further evaluation as $\mathrm{CO}_{2}$ injection test sites (i.e., rated "Very Good") were the Paradise Fossil Plant in Muhlenberg County, Kentucky, and the Johnsonville Fossil Plant in Humphreys County, Tennessee. The Kingston Fossil Plant was rated "Marginal" because of "favorable formations at depths below the Chattanooga Fault, but deep disposal is required." The John Sevier Fossil Plant was rated "Poor" because of "underground structural complexity."

The Tsouris et al. report serves as the starting point for this current assessment. However, because more recent evaluations of sequestration assume that pipelines could be used to transport captured $\mathrm{CO}_{2}$ from the generation site to the sequestration site, in the current assessment the geographic scope of consideration is expanded to a 200-mile radius around the John Sevier and Kingston power plants.

\subsection{RECENT DEVELOPMENTS}

In the five years since the preparation of the Tsouris et al. report, U.S. and international research and development has yielded additional information on technical and economic aspects of geologic carbon sequestration and has refined technical concepts in this area.

The Intergovernmental Panel on Climate Change (IPCC) Special Report on Carbon Dioxide Capture and Storage (2005) conducted a succinct review of sequestration technologies and recent developments, both in the United States and internationally. The IPCC Special Report covers technical, economic, and environmental aspects of geologic sequestration. The candidate technologies with the best near-term potential for geologic sequestration of $\mathrm{CO}_{2}$ rely on different combinations of physical and chemical mechanisms to hold $\mathrm{CO}_{2}$ in place (IPCC 2005). Injection of $\mathrm{CO}_{2}$ into depleted oil and gas fields can enhance recovery of residual hydrocarbons in addition to trapping $\mathrm{CO}_{2}$ in stratigraphic and structural traps that previously contained hydrocarbons. Injection of $\mathrm{CO}_{2}$ into deep saline formations (permeable sedimentary rock formations containing formation waters or brines that 
contain high concentrations of dissolved salts) can provide physical isolation if suitable confining units are present. Deep saline injection can also provide chemical isolation if injected $\mathrm{CO}_{2}$ reacts chemically with dissolved substances in the water, precipitating to form solid carbonate compounds that remain in the aquifer. The efficiency of $\mathrm{CO}_{2}$ injection in depleted oil and gas fields or in saline formations is highest when injection is at great enough depth to maintain $\mathrm{CO}_{2}$ in its very dense and highly fluid supercritical phase. $\mathrm{CO}_{2}$ injected into coal seams can be trapped by adsorption of $\mathrm{CO}_{2}$ onto the coal, displacing trapped methane which can be extracted and consumed as natural gas. As long as the coal remains in the ground, the $\mathrm{CO}_{2}$ should remain isolated, so coals that are considered unmineable are preferred targets (IPCC 2005).

Also since the Tsouris et al. report was prepared, the U.S. Department of Energy's (DOE) Carbon Sequestration Program, directed by the National Energy Technology Laboratory (NETL), has supported additional research and development on sequestration technologies, completed regional inventories of geologic sequestration potential, and initiated small-scale demonstrations of the primary candidate technologies. This program has supported seven regional partnerships evaluating sequestration potential in defined regions of the United States. Areas within a 200-mile radius of the John Sevier and Kingston power plants are within the geographic scope of one of two different regional partnerships: the Southeast Regional Carbon Sequestration Partnership (SECARB), working in the 11-state region of Texas, Louisiana, Mississippi, Alabama, Virginia, North Carolina, South Carolina, Tennessee, Georgia, Arkansas, and Florida, and the Midwest Regional Carbon Sequestration Partnership (MRCSP), working in Maryland, Michigan, Ohio, Pennsylvania, West Virginia, part of Indiana, and eastern Kentucky. In Phase 1 of the NETL Carbon Sequestration Program, which was concluded in 2006, the partnerships inventoried the most promising opportunities for geologic carbon sequestration in their regions. SECARB identified the most promising targets in its region as oil fields in the Gulf Coast region, coal bed methane production areas in the Black Warrior basin (in Alabama) and Central Appalachian basin (in southwestern Virginia and extending into adjacent areas of eastern Kentucky and West Virginia), and salt domes in Mississippi (Nemeth 2006). The most promising targets identified by the MRCSP were deep saline formations in Michigan, Indiana, Ohio, and Pennsylvania (Battelle 2005). The MRCSP also mapped potential capacity in oil and gas fields in Kentucky, West Virginia, Pennsylvania, and Ohio, and in coal beds in Pennsylvania and other states. Additionally, DOE supported the Midcontinent Interactive Digital Carbon Atlas and Relational dataBase (MIDCARB), a consortium of the State Geological Surveys of Illinois, Indiana, Kansas, Kentucky, and Ohio, which mapped potentially suitable geologic reservoirs in the member states (MIDCARB 2007). Phase 2 of the Carbon Sequestration Program, which is in progress, includes field demonstrations of sequestration technology in some of the target areas identified in each region.

The technical criteria used by SECARB and other recent studies to identify potentially suitable targets for sequestration are similar to those used in the Tsouris et al. report, but differ somewhat in detail. In the Tsouris et al. report, technical considerations used in evaluating geologic settings for sequestration in saline aquifers included:

1. Basin origin and tectonic setting (sedimentary basins free of geologic faults were deemed preferable)

2. Known oil, gas, and coal reserves

3. Depths to the $32^{\circ} \mathrm{C}$ isotherm and $7.4 \mathrm{MPa}$ isobar, needed to maintain $\mathrm{CO}_{2}$ in supercritical conditions (the minimum depth for these temperature and pressure conditions was estimated to be 720 to $800 \mathrm{~m}$ )

4. Hydrodynamic regime (long flow paths from the injection site to discharge areas were deemed preferable) 
5. Permeable and porous zones for injection and sequestration (together, permeability and porosity are determinants of storage capacity and feasibility of injection).

For comparison, for injection in saline formations, Smyth et al. (2007) identify the minimum criteria as including: (1) continuity and integrity of an overlying seal; (2) depth sufficient to maintain $\mathrm{CO}_{2}$ at high density (about $800 \mathrm{~m}$ ); (3) depth below underground sources of drinking water and dissolved solids concentrations exceeding $10,000 \mathrm{mg} / \mathrm{L}$; and (4) storage capacity sufficient to prevent displacement of saline water into overlying freshwater-bearing units.

For purposes of the current assessment, all criteria considered in previous screening studies were treated as potentially relevant.

As with the Tsouris et al. report, SECARB found little potential for geologic carbon sequestration in the immediate vicinity of either the John Sevier or Kingston power plants. Both plants are located within the Valley and Ridge province, which is extensively folded and faulted as a result of intense deformation during its geologic history (Tsouris et al. 2002). The Tsouris et al. report suggested that sequestration might be feasible at either power plant site in very deep wells penetrating sedimentary rocks below the uppermost thrust sheet, but that structural complexity and the absence of coal beds limit the potential for sequestration in the Valley and Ridge province. However, the highpotential sequestration targets that SECARB identified in the Black Warrior and Central Appalachian basins are within 200 miles of both plants. Also, the SECARB and MRCSP partnerships identified middle Tennessee and eastern Kentucky as areas with potential capacity for sequestration in deep saline aquifers.

\subsection{OTHER INFORMATION SOURCES}

Additional geologic information and resource assessments are available from state, federal, and university sources. Of particular relevance to this assessment are a pair of evaluations of potential for deep-well injection of wastes in Tennessee conducted by the U.S. Geological Survey in the 1980s (Bradley 1986; Mulderink and Bradley 1986) and a recent evaluation by the Texas Bureau of Economic Geology of potential opportunities for geologic sequestration of $\mathrm{CO}_{2}$ generated in the Carolinas (Smyth et al. 2007).

\subsection{SUMMARY OF METHODOLOGY}

Using the existing sources discussed above, this assessment evaluates updated technology requirements and constraints for each of the technologies potentially applicable to the John Sevier and Kingston power plants (for example, the depth and hydraulic characteristics needed for an injection zone). The assessment examines the stratigraphy, geologic structure, hydraulic properties, and geochemistry of potential injection zones within 200 miles of each plant. To the extent that information is available, the assessment discusses the potential economic costs for various components of geologic sequestration. The results of this assessment are the conclusions presented in Section 5 regarding the potential for geologic sequestration for the John Sevier and Kingston power plants. 


\section{THE TVA POWER PLANTS}

\subsection{JOHN SEVIER FOSSIL PLANT}

TVA's John Sevier Fossil Plant is located on the Holston River near Rogersville, Tennessee (Fig. 1). Construction began on the John Sevier Plant in 1952 and was completed in 1957. The plant has four coal-fired units and generates about 5 billion kilowatt-hours $(\mathrm{kWh})$ of electricity a year. The plant has a winter net dependable generating capacity of 712 megawatts (MW) (TVA 2007a).

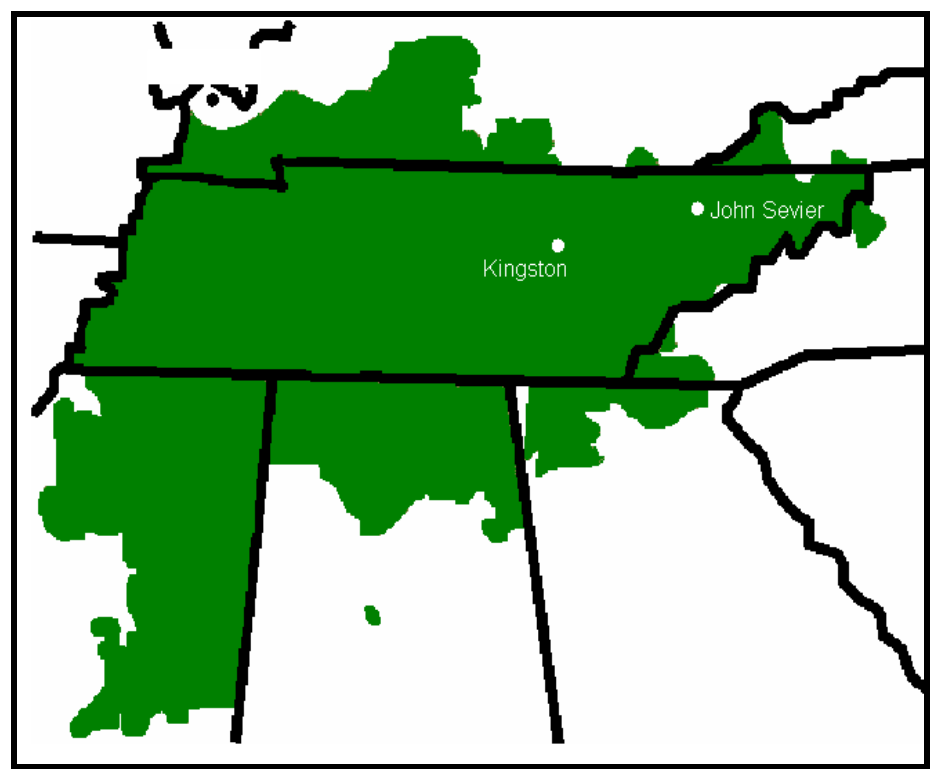

Fig. 1. General location map of the John Sevier and Kingston power plants within the TVA service region (modified from Tsouris et al. 2002).

The John Sevier Plant consumes about 5,700 tons of coal per day and emits about 5.1 million tons (about 4.6 million metric tons) of $\mathrm{CO}_{2}$ per year (see Table 1 and Fig. 2) (TVA 2007a).

Table 1. Annual $\mathrm{CO}_{2}$ emissions

from the John Sevier power plant

\begin{tabular}{cc}
\hline Year & $\begin{array}{c}\text { Million } \\
\text { Tons }\end{array}$ \\
\hline 1996 & 5.4 \\
1997 & 5.0 \\
1998 & 5.4 \\
1999 & 5.5 \\
2000 & 5.5 \\
2001 & 5.3 \\
2002 & 5.2 \\
2003 & 5.3 \\
2004 & 5.3 \\
2005 & 5.0 \\
2006 & 5.1 \\
\hline
\end{tabular}

Source: TVA 2007a 


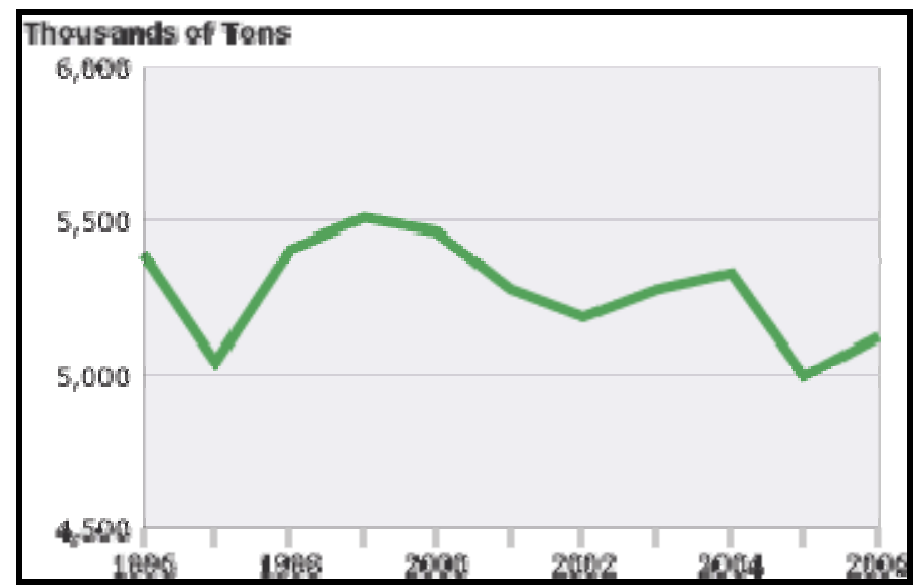

Fig. 2. Annual $\mathrm{CO}_{2}$ emissions from the John Sevier power plant (TVA 2007a)

\subsection{KINGSTON FOSSIL PLANT}

TVA's Kingston Fossil Plant is located on Watts Bar Reservoir on the Tennessee River near Kingston, Tennessee (Fig. 1). Construction began on the Kingston Plant in 1951 and was completed in 1955. At the time it was finished, the Kingston Plant was the largest coal-burning power plant in the world, a distinction it held for more than a decade. The plant has nine coal-fired units and generates about 10 billion $\mathrm{kWh}$ of electricity a year. The plant has a winter net dependable generating capacity of 1,456 MW (TVA 2007b).

The Kingston Plant consumes about 14,000 tons of coal per day and emits about 11.0 million tons of $\mathrm{CO}_{2}$ per year (see Table 2 and Fig. 3) (TVA 2007b).

Table 2. Annual $\mathrm{CO}_{2}$ emissions from the Kingston power plant

\begin{tabular}{cc}
\hline Year & $\begin{array}{c}\text { Million } \\
\text { Tons }\end{array}$ \\
\hline 1996 & 9.8 \\
1997 & 9.7 \\
1998 & 10.3 \\
1999 & 10.1 \\
2000 & 10.7 \\
2001 & 10.4 \\
2002 & 11.0 \\
2003 & 11.2 \\
2004 & 10.4 \\
2005 & 10.3 \\
2006 & 11.0 \\
\hline
\end{tabular}

Source: TVA 2007b 


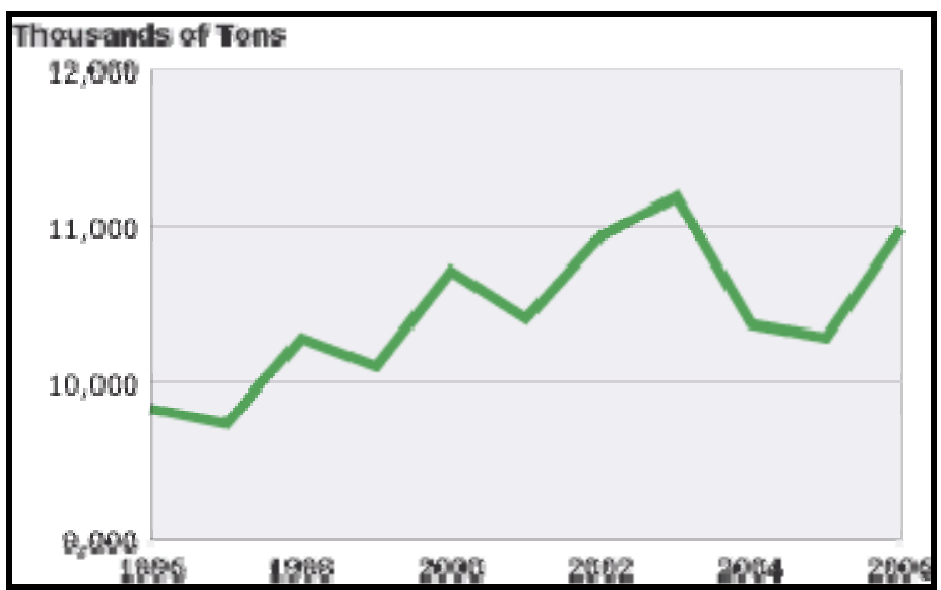

Fig. 3. Annual $\mathrm{CO}_{2}$ emissions from the Kingston power plant (TVA 2007b).

\section{ASSESSMENT}

ORNL prepared a report on the on-site sequestration potential for TVA's 11 fossil fuel power plants in 2002 (Tsouris et al. 2002), considering geologic and hydrologic factors. That report provides extensive information on the geology and hydrology of the region, and discusses the potential for sequestration in the immediate vicinity of TVA's coal-burning electric plants. Potential geologic sequestration targets were identified near several plants, primarily in deep saline formations, including the Cambrian-Ordovician age Knox Group and the basal sandstone found at the base of the regional sedimentary rock sequence. The Tsouris et al. report found little potential for geologic carbon sequestration in the immediate vicinity of either the John Sevier or Kingston power plants. Both plants are within the Valley and Ridge province, which is extensively folded and faulted as a result of intense deformation during its geologic history (Tsouris et al. 2002). Structural complexity and the absence of coal beds limit the potential for sequestration in this province.

Because more recent evaluations of sequestration assume that pipelines could be used to transport captured $\mathrm{CO}_{2}$ from the generation site to the sequestration site, in the current assessment the geographic scope of consideration is expanded to a 200-mile radius around the John Sevier and Kingston plants. This expanded geographic scope results in consideration of potential sequestration locations and geologic settings not considered in the Tsouris et al. report, notably including sequestration in coal seams. Because there are no major coal-production regions in the close proximity of any TVA plants, the Tsouris et al. study provided only minimal treatment of this geologic setting as a potential sequestration target.

This assessment also reviews new information on the economic costs of geologic sequestration, based primarily on information reported in the IPCC Special Report on Carbon Dioxide Capture and Storage (2005).

\subsection{GEOLOGIC SUITABILITY FOR CARBON SEQUESTRATION}

This section reviews available information on geologic settings within approximately 200 miles of the John Sevier and Kingston power plants that are potentially suitable for carbon sequestration. The 200-mile radius is used for evaluation as an approximate upper limit on the economically feasible distance for pipeline transport of $\mathrm{CO}_{2}$ for sequestration. In several figures in 
this section, rough delineations of the regions within 200 miles of the two power plants are overlaid on resource maps for illustrative purposes. In some instances these delineations may be distorted as a result of idiosyncrasies of map projections and scaling, so these illustrations should not be considered accurate indications of distance.

\subsubsection{NETL Carbon Sequestration Program Findings}

As part of Phase 1 of the NETL Carbon Sequestration Program, which was concluded in 2006, SECARB inventoried the most promising opportunities for geologic carbon sequestration in the 11-state region of Texas, Louisiana, Mississippi, Alabama, Virginia, North Carolina, South Carolina, Tennessee, Georgia, Arkansas, and Florida (Nemeth 2006). Most areas within 200 miles of the John Sevier and Kingston power plants are located within the northeastern part of the SECARB region, which includes Tennessee, North Carolina, and Virginia. The draft final report from Phase I of the SECARB activity recommends additional geologic characterization in the northeastern part of the SECARB region, stating that the geologic suitability of this subregion for carbon sequestration is uncertain due to incomplete information (Nemeth 2006). In this subregion, however, SECARB identified potential targets for geologic sequestration in unmineable coal seams and deep saline aquifers. SECARB also stated that depleted gas fields and abandoned gas storage fields may be future targets, and there may be local opportunities for sequestering $\mathrm{CO}_{2}$ as part of enhanced oil recovery operations.

The MRCSP component of the Carbon Sequestration Program inventoried potential geologic sequestration capacity in Maryland, Michigan, Ohio, Pennsylvania, West Virginia, part of Indiana, and eastern Kentucky, identifying deep saline rock formations as its region's "largest assets for longterm geologic $\mathrm{CO}_{2}$ sequestration," with some capacity found in each of the seven states in the region (DOE 2006). Oil and natural gas production in the MRCSP region (including oil and gas fields within 200 miles of both of the TVA plants, in eastern Kentucky and West Virginia) often occurs from deep saline formations, so a high potential exists for enhanced oil and gas production associated with $\mathrm{CO}_{2}$ sequestration (DOE 2006).

The following sections focus on potential opportunities for sequestration in the two geologic settings evaluated as most favorable by SECARB and MRCSP: coal seams and deep saline formations. Sequestration may be feasible in the future in other geologic settings present in the region, but these two types of settings appear to be most favorable for implementing sequestration in the near term.

\subsubsection{Potential for Sequestration in Coal Seams}

The SECARB region has extensive coal resources (Fig. 4), including both mineable coals and coals that may not be economically recoverable. Coal seams that are deep (generally below 2,400 ft), unlikely to be mineable, and have high methane gas content may be suitable for utilizing $\mathrm{CO}_{2}$ to enhance the recovery of coal bed methane while accomplishing the long-term storage of $\mathrm{CO}_{2}$. Variables controlling carbon sequestration potential in coal beds are similar to those that determine potential for coal bed methane production. Within the SECARB region, coal bed methane is currently being produced commercially in the Black Warrior Basin of Alabama and the Pocahontas Basin (part

of a region also called the Central Appalachian Province) in southwestern Virginia (Fig. 5). SECARB identified coal bed methane reservoirs in these two basins as having the greatest potential for both carbon sequestration and coal bed methane production due to several factors, including high methane gas content in coals, favorable reservoir properties, and the infrastructure already in place in the area. 
The Black Warrior Basin lies largely outside the 200-mile radius of the two TVA power plants (Fig. 5), so it is not considered a potential area for sequestration of $\mathrm{CO}_{2}$ from these facilities. The Pocahontas Basin is, however, less than 100 miles from the John Sevier plant and near the 200-mile distance from the Kingston plant (Fig. 5), making it a potential candidate area for sequestration of $\mathrm{CO}_{2}$ from either plant.

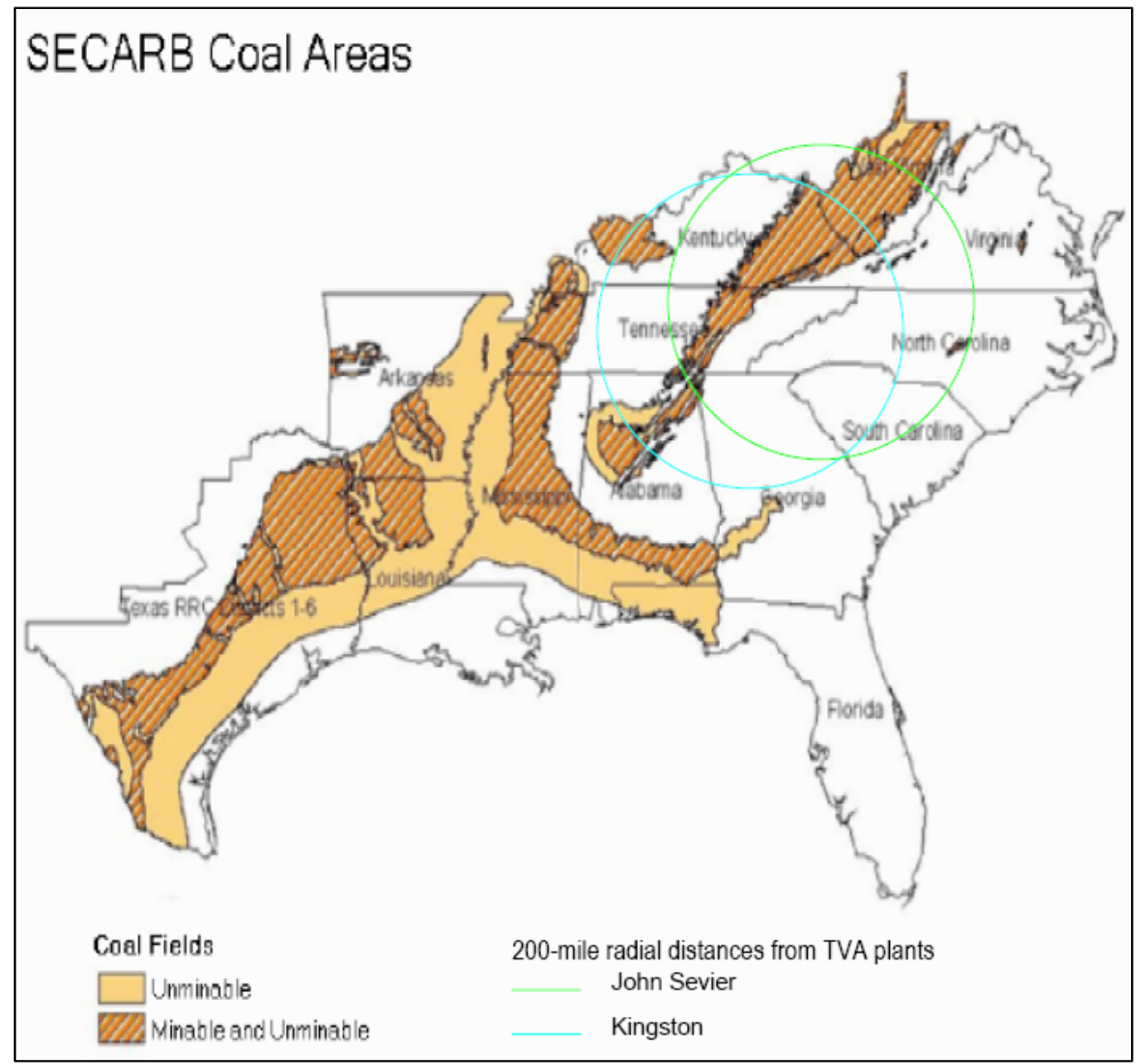

Fig. 4. Locations of coal resources within approximately 200 miles of TVA's John Sevier and Kingston power plants (modified from SECARB 2005)

Coal in the Pocahontas Basin that is potentially suitable for sequestration is of Pennsylvanian age, in multiple seams with composite thicknesses ranging from 4.5 to over $9 \mathrm{~m}$ of net coal. The prospective coal seams are mostly low to medium volatile bituminous, with high gas contents of 5.6 to over $17 \mathrm{scm}^{1}$ per ton (200 to $600+\mathrm{scf}^{2}$ per ton), and occur at favorable depths for carbon storage. The extensive coal bed methane development in the area (there were over 3,500 coal bed methane wells in the Central Appalachian Basin as of 2004) has provided extensive geological, engineering, and production data for use in modeling sequestration potential, and the area's methane productivity indicates that coal permeabilities should be acceptable for $\mathrm{CO}_{2}$ injection (SECARB 2005).

\footnotetext{
${ }^{1} \mathrm{scm}=$ standard cubic meters, indicates volume of gas at standard temperature and pressure of $60{ }^{\circ} \mathrm{F}$ and one atmosphere

${ }^{2} \mathrm{scf}=$ standard cubic feet, a volume of gas at standard temperature and pressure
} 


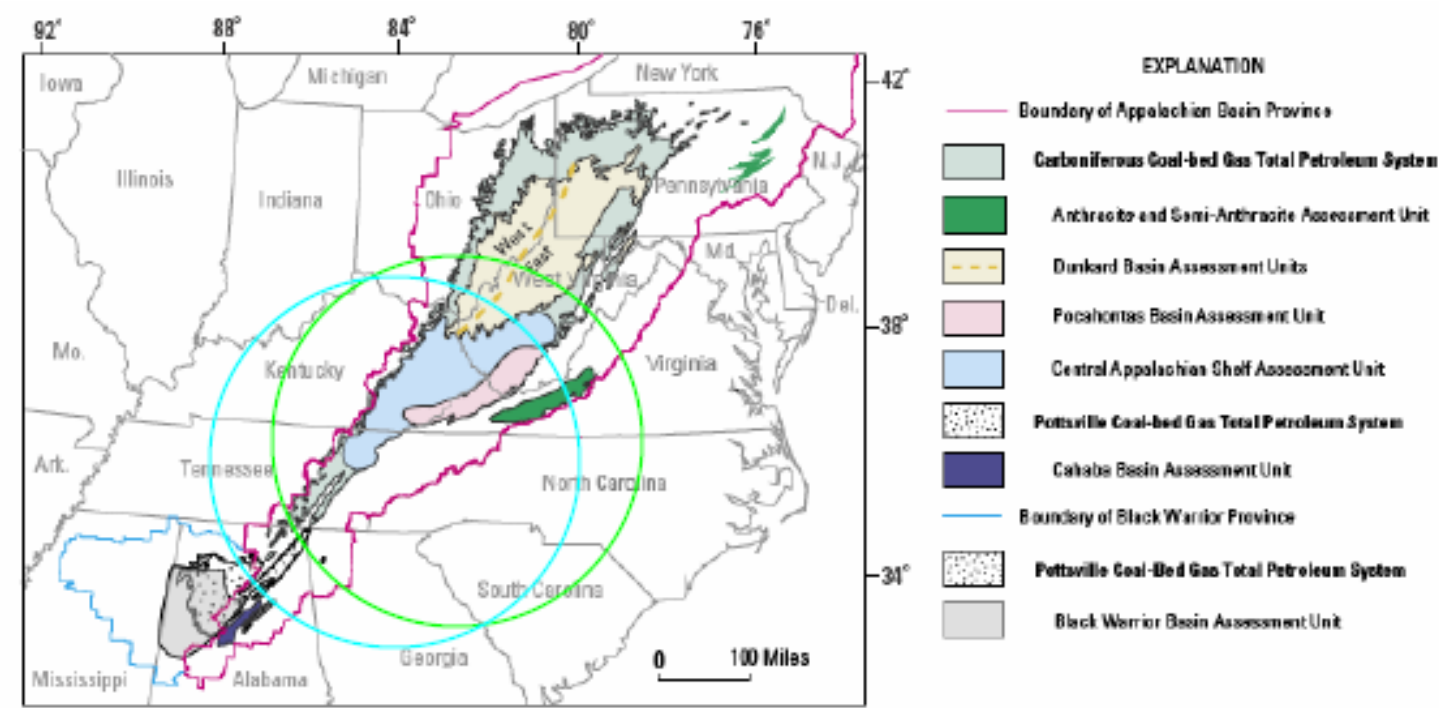

Fig. 5. Locations of named coal basins in the Appalachian Basin relative to 200-mile distances from TVA's John Sevier and Kingston power plants (modified from Milici and Hatch 2004).

The Virginia Center for Coal and Energy Research (2007), a participant in SECARB, has identified mature coal bed methane production areas in Buchanan and Dickenson Counties, Virginia, as ideal areas for sequestration, based on consideration of net coal thickness, coal rank, coal isotherm, and the need to avoid areas where deep mining has occurred in the past or where deep mining permits have been issued. Figure 6 shows the locations of commercial coal bed methane production in these two counties, and Figs. 7 and 8 show (respectively) in-place gas content and total coal thicknesses in the area. The coal seams with the highest potential for coal bed methane production (and thus, carbon sequestration) are at depths of about 1,000 to 2,000 feet (EPA 2004). SECARB has estimated that the

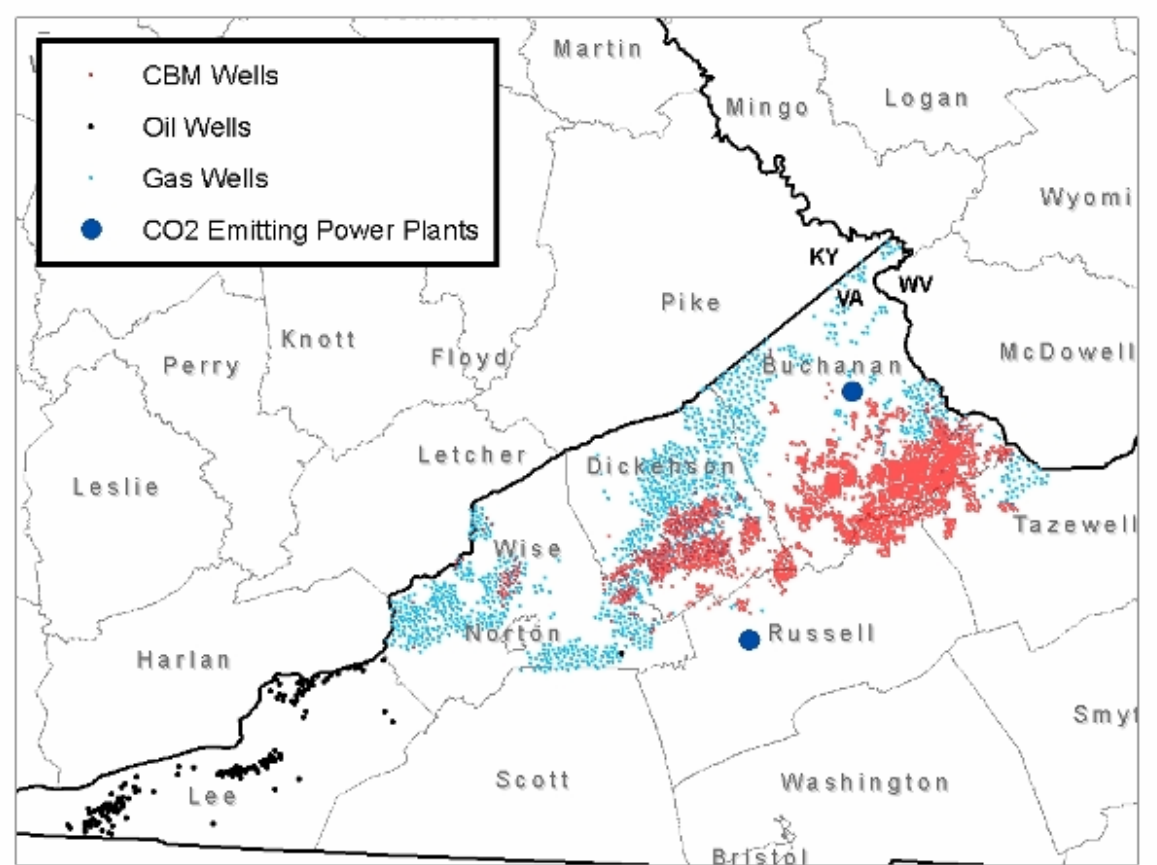

Fig. 6. Locations of oil, gas, and coal bed methane (CBM) wells in the Pocahontas Basin in southwestern Virginia (Virginia Center for Coal and Energy Research 2007) 


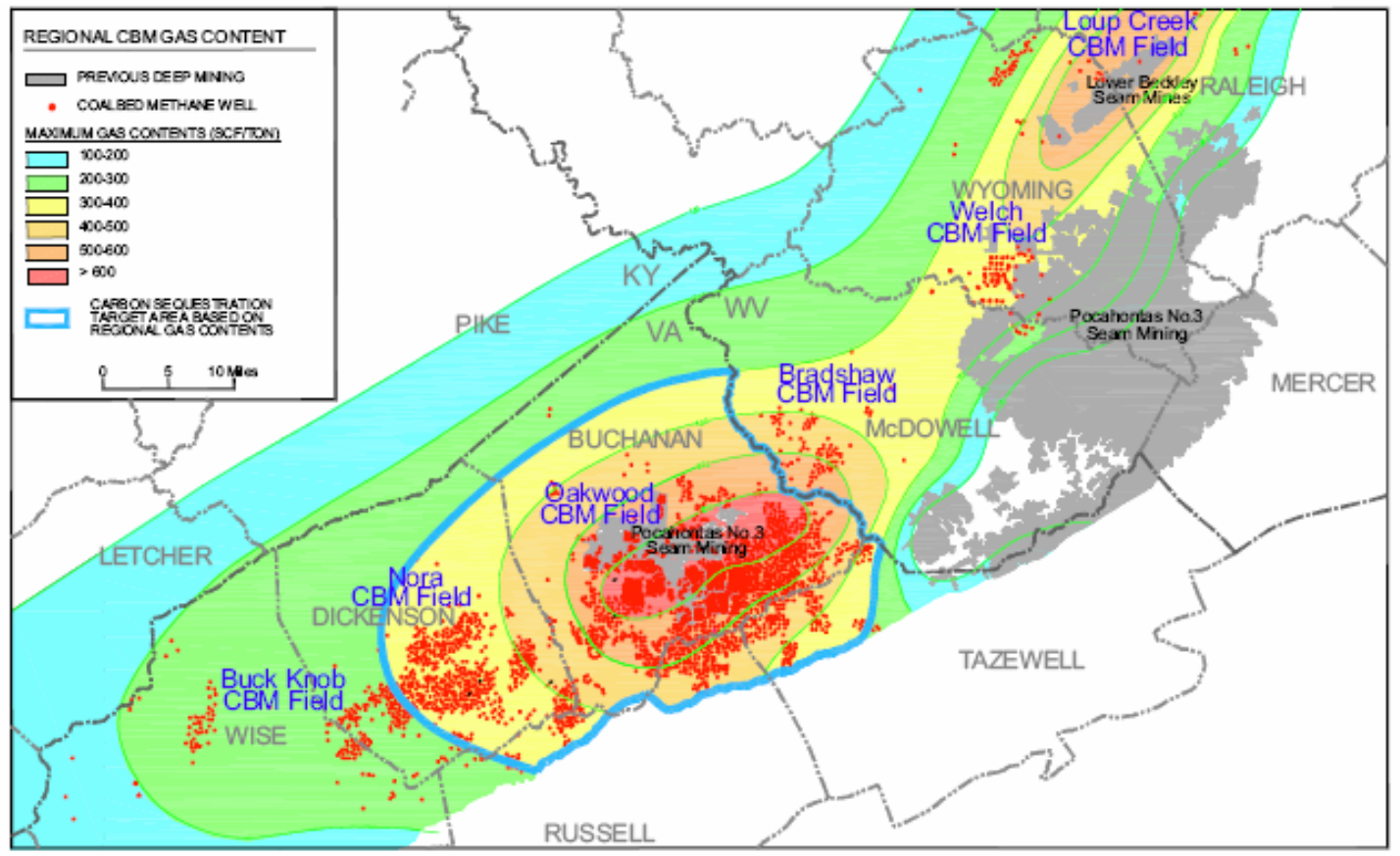

Fig. 7. In-place methane gas content in coal seams in a portion of the Pocahontas Basin, Virginia, Kentucky, and West Virginia (Conrad et al. 2006).

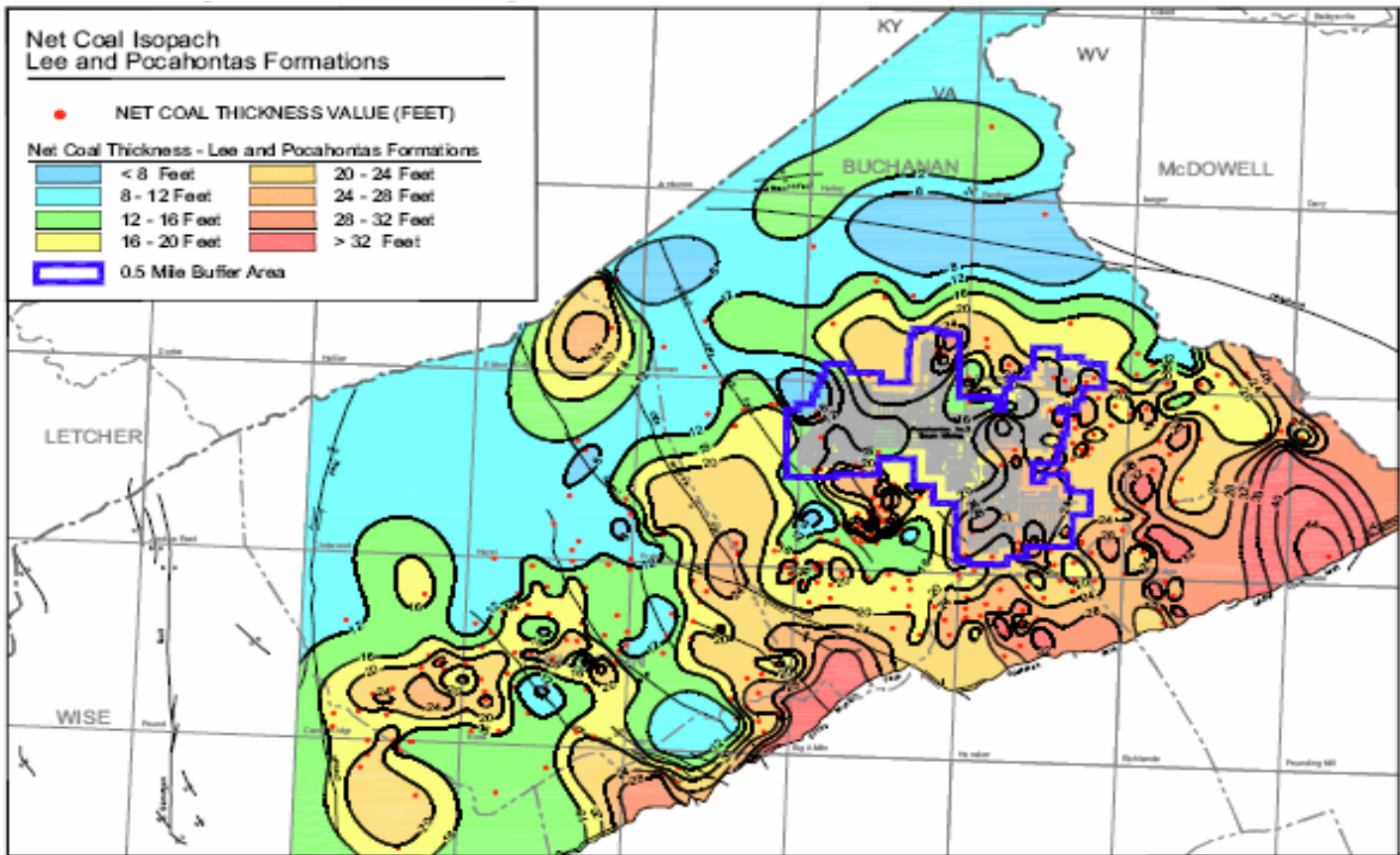

Fig. 8. Total coal thickness in the Lee and Pocahontas Formations in a portion of the Pocahontas Basin, southwestern Virginia (Conrad et al. 2006). 
Buchanan-Dickenson two-county area has capacity for sequestration of 308 to 818 million metric tons of $\mathrm{CO}_{2}$ in Pennsylvanian-age coal seams in the Pocahontas Formation and the overlying lower and middle Lee Formation (DOE 2006). SECARB participants further estimated that 0.8 to 0.9 trillion $\mathrm{ft}^{3}$ of coal bed methane could be recovered in this basin as a result of $\mathrm{CO}_{2}$ sequestration (Nemeth 2006; Conrad et al. 2006). One of the SECARB field demonstrations of $\mathrm{CO}_{2}$ sequestration is being done in the Pocahontas Basin, using horizontal wells (Virginia Center for Coal and Energy Research 2007).

SECARB also identified portions of the Pocahontas Basin in McDowell and Wyoming Counties in West Virginia (see Fig. 6 for locations of these counties) as potentially favorable for carbon sequestration (SECARB 2005). (SECARB extended its inventory of coal beds with potential for use in sequestration into adjoining areas of Kentucky and West Virginia with similar geology.)

An EPA study (2004) recommended that the vertical relationship between coal seams and underground sources of drinking water in the Pocahontas Basin should be determined on a sitespecific basis before conducting hydraulic fracturing for coal bed methane recovery. In the western part of the basin coal seams considered potentially suitable for sequestration occur at depths of over $2,000 \mathrm{ft}$, which should be well below aquifers that can supply water with less than $10,000 \mathrm{mg} / \mathrm{L}$ dissolved solids, but the possibility exists that production from shallower coal seams in the eastern portion of the basin could adversely affect water quality in aquifers that could be suitable for drinking water supply (EPA 2004).

\subsubsection{Potential for Sequestration in Deep Saline Formations}

Several recent screening studies have identified potential opportunities for $\mathrm{CO}_{2}$ sequestration in deep saline formations within the region of interest.

\subsubsection{Potential Reservoirs Identified by Regional Screening Studies}

The Carbon Sequestration Atlas developed during Phase I of the DOE Carbon Sequestration Program (DOE 2006) identifies the Mt. Simon Sandstone in Middle Tennessee (Fig. 9) and the Rose Run Sandstone in eastern Kentucky (Fig. 10) as deep saline rock layers with potential for geologic sequestration of $\mathrm{CO}_{2}$. The Mt. Simon Sandstone in Tennessee was estimated to have capacity for 1,250 to 5,000 million metric tons of $\mathrm{CO}_{2}$, and the Rose Run Sandstone was estimated to have capacity for 19,700 million metric tons of $\mathrm{CO}_{2}$ in the four-state region where it was mapped by the MRCSP (DOE 2006). The MRCSP noted that many oil and gas fields in its region are intermixed with deep saline aquifers, so a high potential exists for enhanced oil and gas production associated with $\mathrm{CO}_{2}$ sequestration (DOE 2006). For example, the Rose Run Sandstone is a hydrocarbon reservoir tapped by oil and gas wells in both Ohio and Kentucky (Riley et al. 2003).

The Texas Bureau of Economic Geology (TBEG) evaluated data for the states of North Carolina and South Carolina and the surrounding region to identify deep saline reservoirs that might offer opportunities for geologic sequestration of $\mathrm{CO}_{2}$ generated in the Carolinas (Smyth et al. 2007). Within the region of interest near the John Sevier and Kingston power plants, their evaluation identified the Mt. Simon Formation in Tennessee and the Knox Group in Kentucky and West Virginia as saline reservoirs that might be suitable for $\mathrm{CO}_{2}$ sequestration (Fig. 11). Although the Rose Run Sandstone is a unit within the Knox Group and there is substantial overlap between the region where TBEG mapped sequestration potential in the Knox Group and the region where the MRCSP mapped sequestration potential in the Rose Run unit, the two mapped regions are not identical (compare Figs. 10 and 11). Smyth et al. (2007) estimated that the Knox Group in Kentucky and West Virginia has capacity for 30,000 million metric tons of $\mathrm{CO}_{2}$ (this is more than $50 \%$ higher than SECARB's 


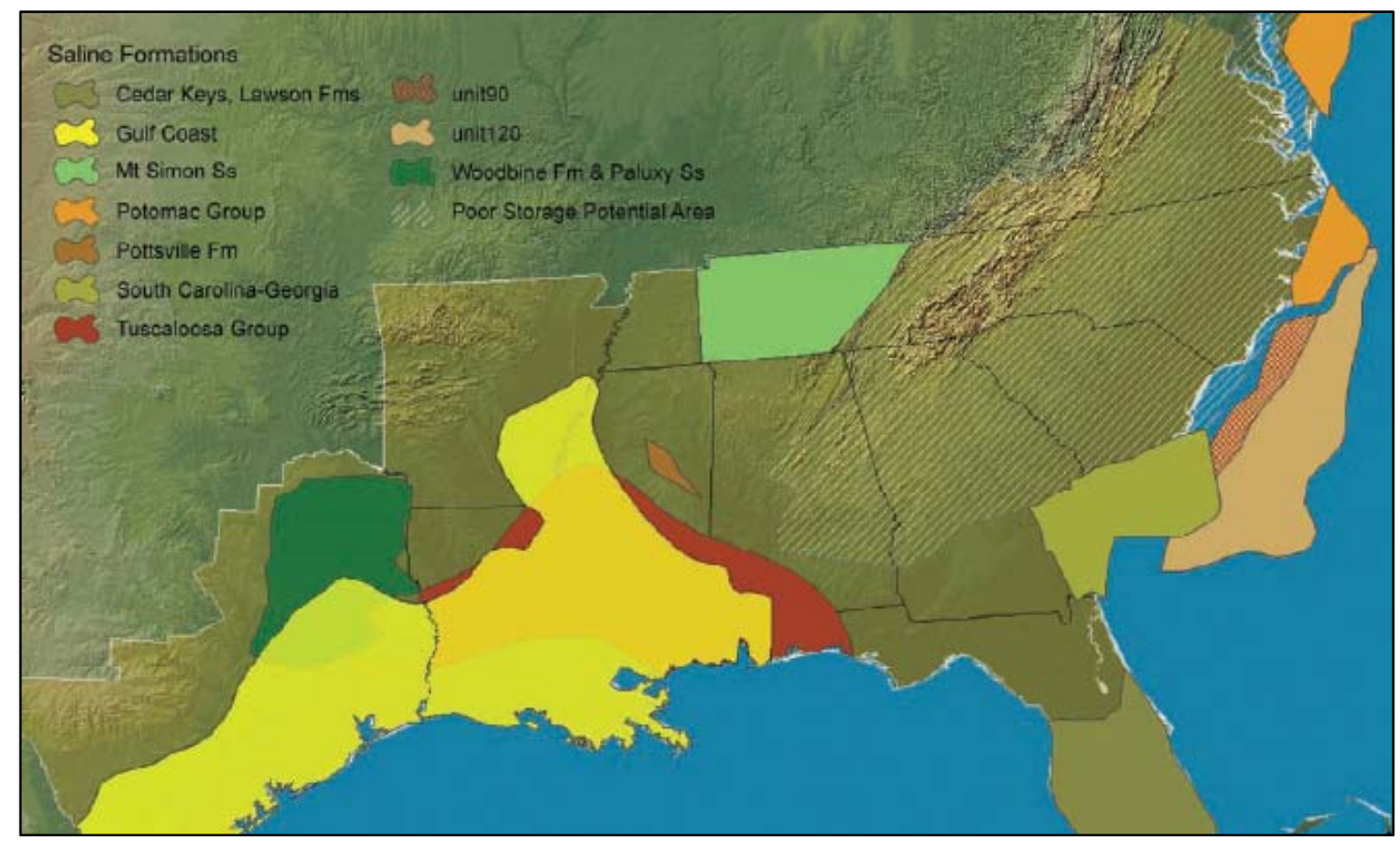

Fig. 9. Saline formations in Tennessee and other states identified by SECARB as having sequestration potential (modified from DOE 2006).

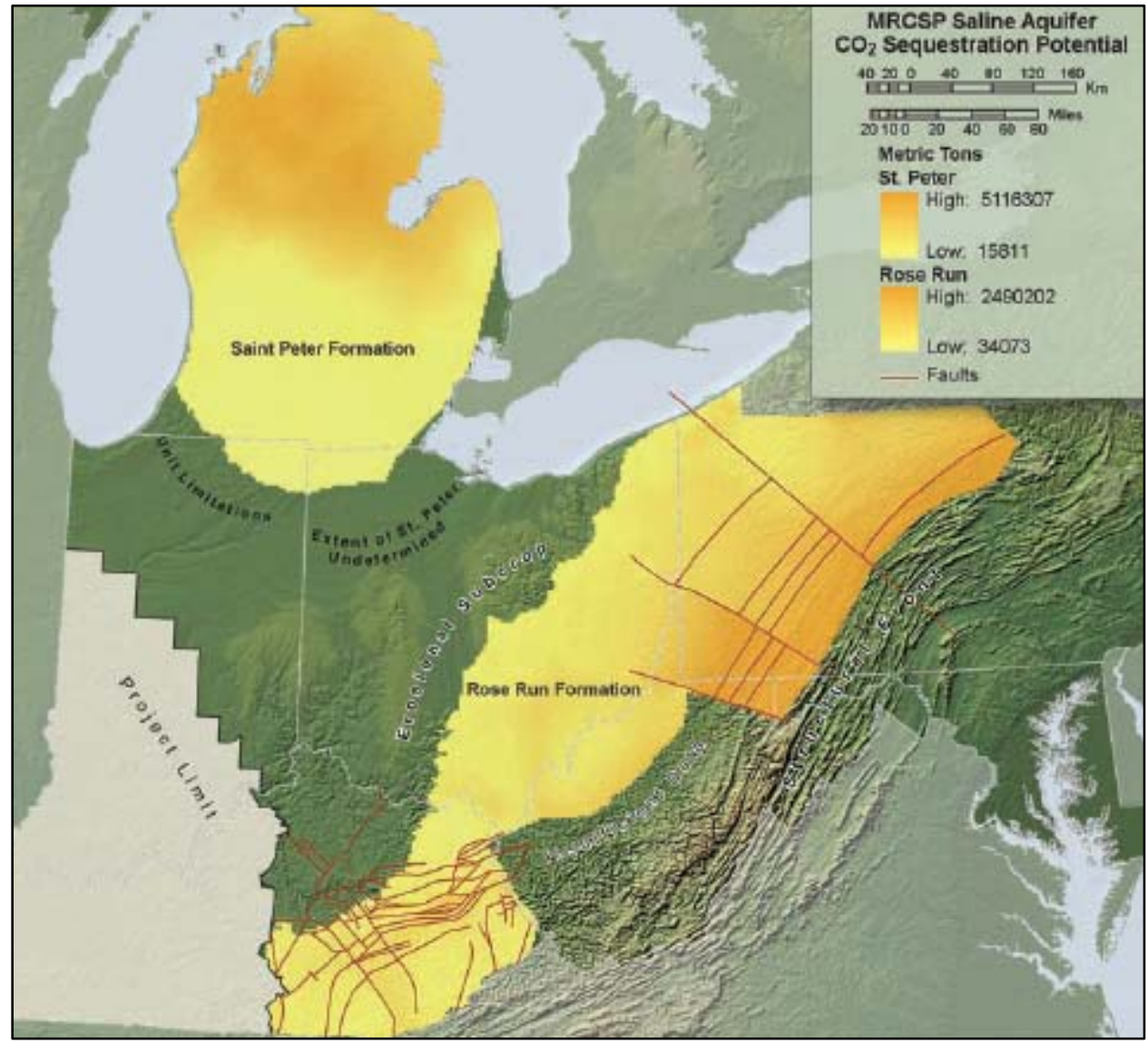

Fig. 10. Saline sandstone formations in Kentucky and other states identified by MRCSP as having sequestration potential (DOE 2006).

The Rose Run unit is not mapped in southeastern West Virginia due to "insufficient data." 


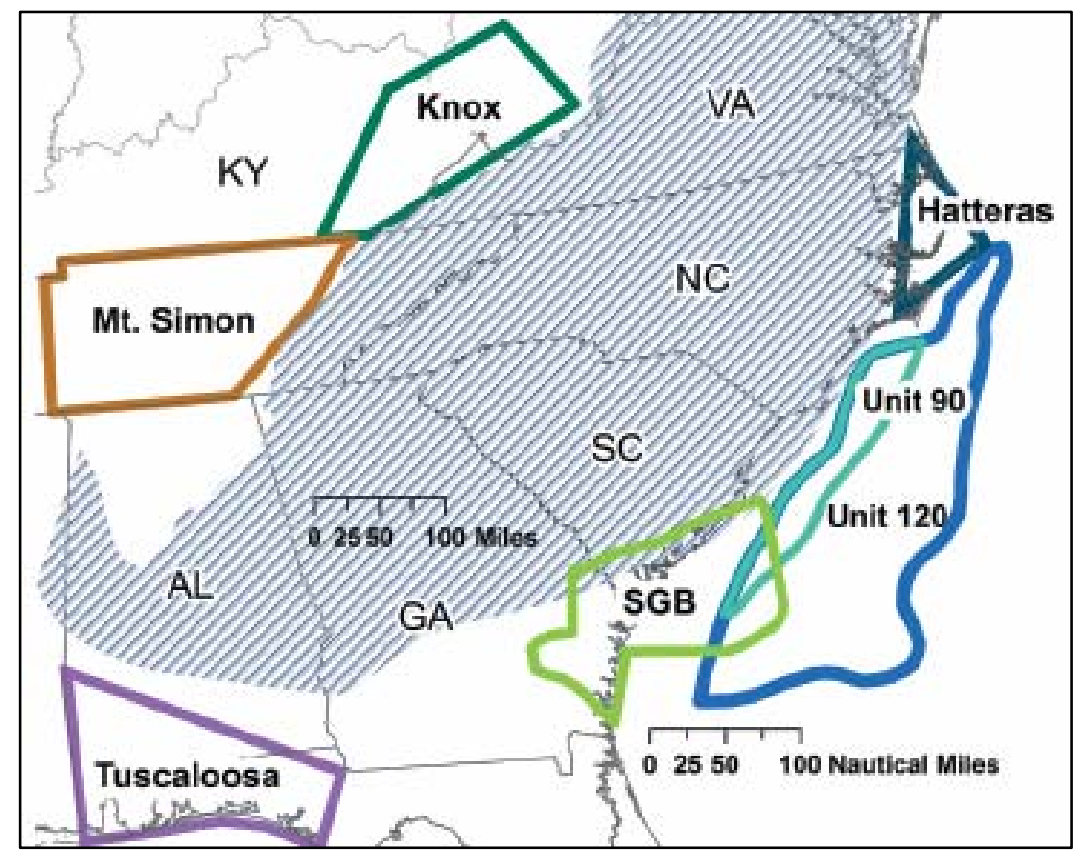

Fig. 11. Areas where TBEG identified high-potential geologic sinks in the vicinity of the Carolinas.

Stippling indicates areas with low sequestration potential (modified from Smyth et al. 2007).

19,700 million metric ton estimate of the capacity available in the Rose Run unit in a four-state region).

The following subsections explore the potential for sequestration in the two principal geologic units identified in the regional screening studies.

\subsubsection{Basal Sandstone Unit in Tennessee}

SECARB (DOE 2006) and TBEG (Smyth et al. 2007) identified potential capacity in the Mt. Simon Sandstone in Tennessee. The Mt. Simon formation, which is recognized in a large region of the mid-continent, is not generally recognized in Tennessee. Apparently SECARB and TBEG extended stratigraphic nomenclature from the mid-continent into the state of Tennessee, applying the name "Mt. Simon Sandstone" to an unnamed unit (possibly stratigraphically equivalent to the lower Cambrian-age Rome Formation found in the Valley and Ridge province) that is typically referred to within Tennessee as the "basal sandstone." In the remainder of this discussion, this unit is referred to as the "basal sandstone;" this same terminology is used in the 2002 ORNL report (Tsouris et al. 2002).

According to Smyth et al. (2007), the basal sandstone is approximately $30 \mathrm{~m}$ (100 ft) thick throughout middle Tennessee and is found at depths from 1200 to $2400 \mathrm{~m}$, placing it within the depth range potentially suitable for sequestration of supercritical $\mathrm{CO}_{2}$. Figure 12 shows contours of the depth to the base of the sandstone unit in middle Tennessee, based on data compiled by Advanced Resources International (Smyth et al. 2007). Smyth et al. estimated the unit's $\mathrm{CO}_{2}$ sequestration capacity as about 2,500 million metric tons (this value is in the middle of the range of estimates provided by SECARB). 


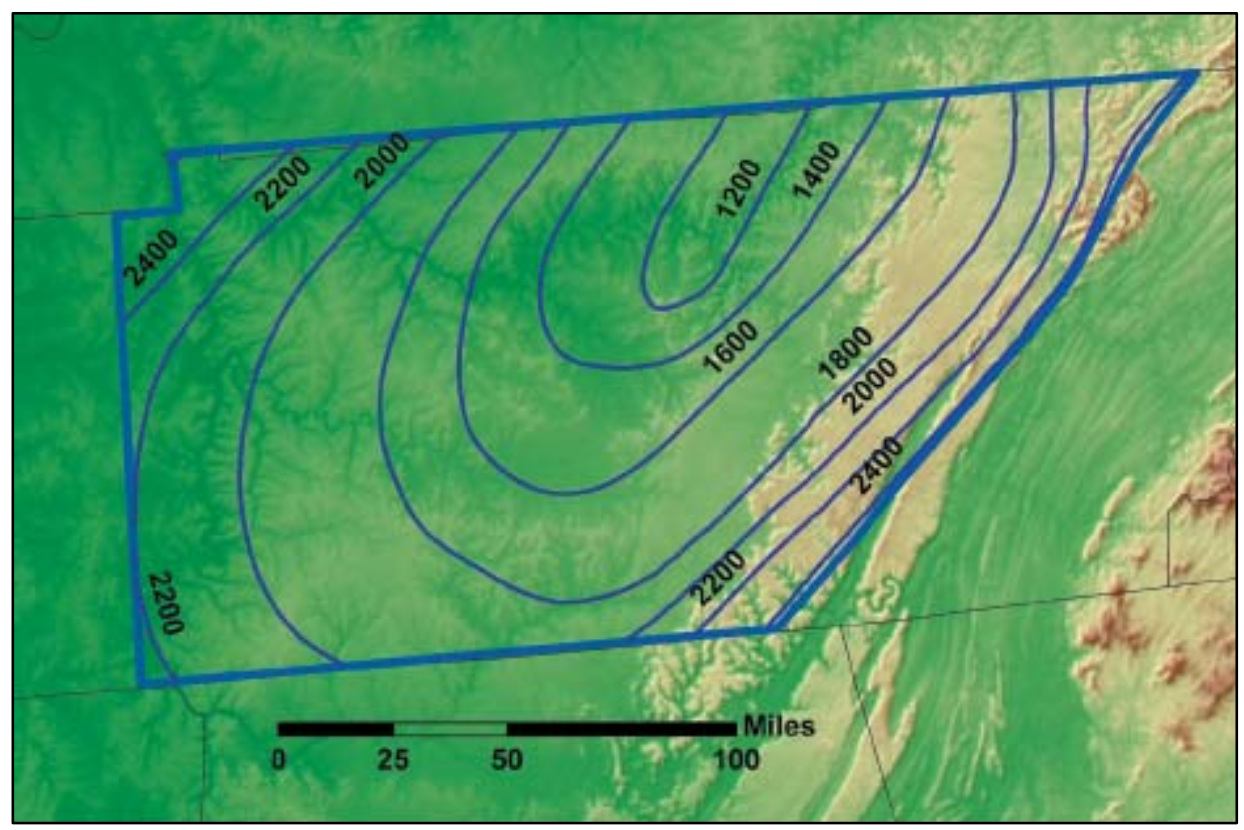

Fig. 12. Depth in meters to the base of the basal sandstone in middle Tennessee (Smyth et al. 2007).

The area of middle Tennessee assessed as having sequestration capacity in the basal sandstone is within approximately 10 to 200 miles from the Kingston power plant, and part of the area lies within approximately 50 to 200 miles from the John Sevier power plant (Fig. 13).

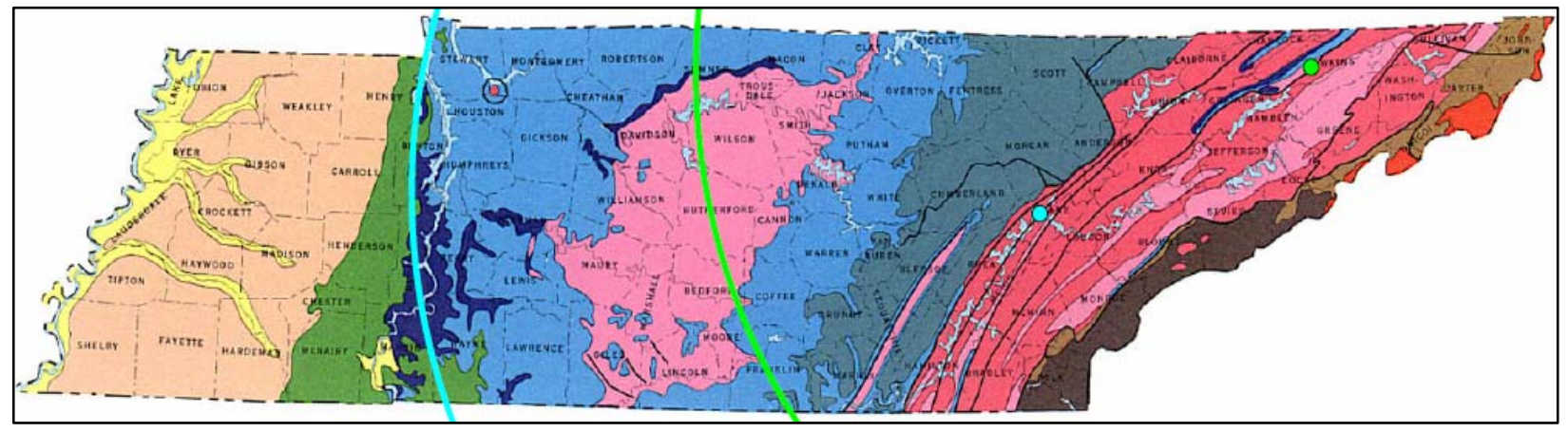

Fig. 13. Geologic map of Tennessee with approximate locations of the John Sevier (green) and Kingston (blue) power plants and arcs indicating the 200-mile distances from the plants (modified from Tennessee Division of Geology, undated).

Mulderink and Bradley (1986) reviewed available data to assess the suitability of the basal sandstone in middle and west Tennessee as a potential zone for deep-well injection of liquid wastes. At the time of their report, just 14 wells were known to have penetrated this unit in middle and west Tennessee, encountering it at depths ranging from 5,045 ft in DeKalb County to 9,960 ft in Cumberland County. Their report stated that the unit is at depths of 5,000 to 9,000 ft (about 1,500 to $2,700 \mathrm{~m}$; this is a somewhat larger range of depths than identified in the recent screening studies), with all depths in the range appropriate for supercritical $\mathrm{CO}_{2}$. Well logs showed the unit's thickness 
as ranging from about $30 \mathrm{ft}$ to more than $700 \mathrm{ft}$ (about $10 \mathrm{~m}$ to more than $200 \mathrm{~m}$; this is much higher variation than identified in the recent screening studies). According to Mulderink and Bradley, all available water samples (from four wells) had dissolved solids concentrations exceeding $10,000 \mathrm{mg} / \mathrm{L}$ and the basal sandstone is well separated from overlying water-supply aquifers, meeting suitability screening criteria for injection of wastes (or $\mathrm{CO}_{2}$ ). However, porosity and permeability were relatively low.

There is a history of deep-well injection of wastes into wells penetrating the basal sandstone at New Johnsonville in Humphreys County and Mt. Pleasant in Maury County in western middle Tennessee (Mulderink and Bradley 1986). Three wells (two wells at New Johnsonville and one at Mt. Pleasant) were used to inject liquid industrial wastes into an injection zone that extended from the lower Knox Group through the Conasauga Group and the basal sandstone to the top of the Precambrian "basement" (well log data reviewed in the Tsouris et al. report suggest that the vertical dimension of the injection zone was 2,000 ft or more; however, within this thick vertical sequence there are only a few discrete intervals with capacity to receive injected wastes).

Tsouris et al. (2002) reported that in 1969 DuPont Corporation had found the basal sandstone unit at Old Hickory, Tennessee (near the county line between Sumner and Davidson counties) to consist of fine grained sand with an average porosity of 9.2\% (1.7-14.9\%) and an average permeability of $15.9 \mathrm{md}^{3}(0.1-132 \mathrm{md})$. DuPont deemed the unit to be "not feasible" for proposed injection of wastes because desired injection rates could not be maintained with natural permeability and porosity (hydrofracturing would be needed). Tsouris et al. also reviewed information from DuPont testing of the basal sandstone and overlying units at a DuPont site near the TVA Johnsonville fossil plant in Humphreys County. (Note that permeability and porosity values deemed inadequate for injection of aqueous wastes might be sufficient for injection of supercritical $\mathrm{CO}_{2}$, which has different physical properties, including significantly lower viscosity than water. Tsouris et al. cited the minimum permeability for $\mathrm{CO}_{2}$ sequestration as $0.050-0.100 \mu \mathrm{m}^{2}$, which equates to 0.005 to $0.01 \mathrm{md}$.).

If geologic units above the basal sandstone also could be used for sequestration, a single well could be used to inject $\mathrm{CO}_{2}$ into multiple injection zones, thus enhancing the technical and economic feasibility of sequestration in this unit. Tsouris et al. (2002) noted that a New Johnsonville area well tested by DuPont apparently had permeable zones above the basal sandstone, in both the Conasauga Group (6,000-6,400 ft depth) and the lower Knox Group (4,400-5,400 ft depth). Tsouris et al. stated:

Core analyses show a very good zone in the lower Knox at 4,410-4,448 ft. In this core, permeability was $110 \mathrm{md}$ and porosity was $10.7 \%$. A second good zone was present in the Conasauga at $6,038 \mathrm{ft}$, with a permeability of $27 \mathrm{md}$ and porosity of $5.2 \%$. Other core samples had reasonable permeability values $(\sim 5-10 \mathrm{md})$ but only $1-2 \%$ porosity.

Permeable horizons in the Conasauga and lower Knox Group may be suitable for sequestration if they are deep enough (below about 2,500 ft depth), have appropriate host rock chemistry and sufficiently high salinity, and are effectively separated from overlying water supply aquifers. The Knox Group is mined for zinc in Smith County in middle Tennessee, and the upper Knox aquifer (the uppermost 200-300 ft of the Knox Group) is a source of water supply, particularly in Tennessee's Central Basin and the Sequatchie Valley (Fig. 14), but data on the Conasauga and lower Knox in middle Tennessee are sparse (Bradley 1986). The Knox Group is several thousand feet

\footnotetext{
${ }^{3} \mathrm{md}=$ millidarcy, a unit of intrinsic permeability equal to $1.01 \times 10^{5} \mathrm{~cm}^{2}$. The hydraulic conductivity (permeability to water) equivalent to one millidarcy is $9.66 \times 10^{-9} \mathrm{~m} / \mathrm{s}$.
} 
thick (it can be reliably assumed to be at least $2,000 \mathrm{ft}$ thick throughout middle Tennessee); depth to the top of the unit is as little as $350 \mathrm{ft}$ in the Central Basin but ranges up to more than 2,000 $\mathrm{ft}$ in west Tennessee and more than 3,000 ft in the Cumberland Plateau (Bradley 1986; see Fig. 14 for physiographic references). Thus, in the Cumberland Plateau and most of the Eastern and Western Highland Rim provinces the lower Knox should be sufficiently deep to maintain sequestered $\mathrm{CO}_{2}$ in a supercritical phase.

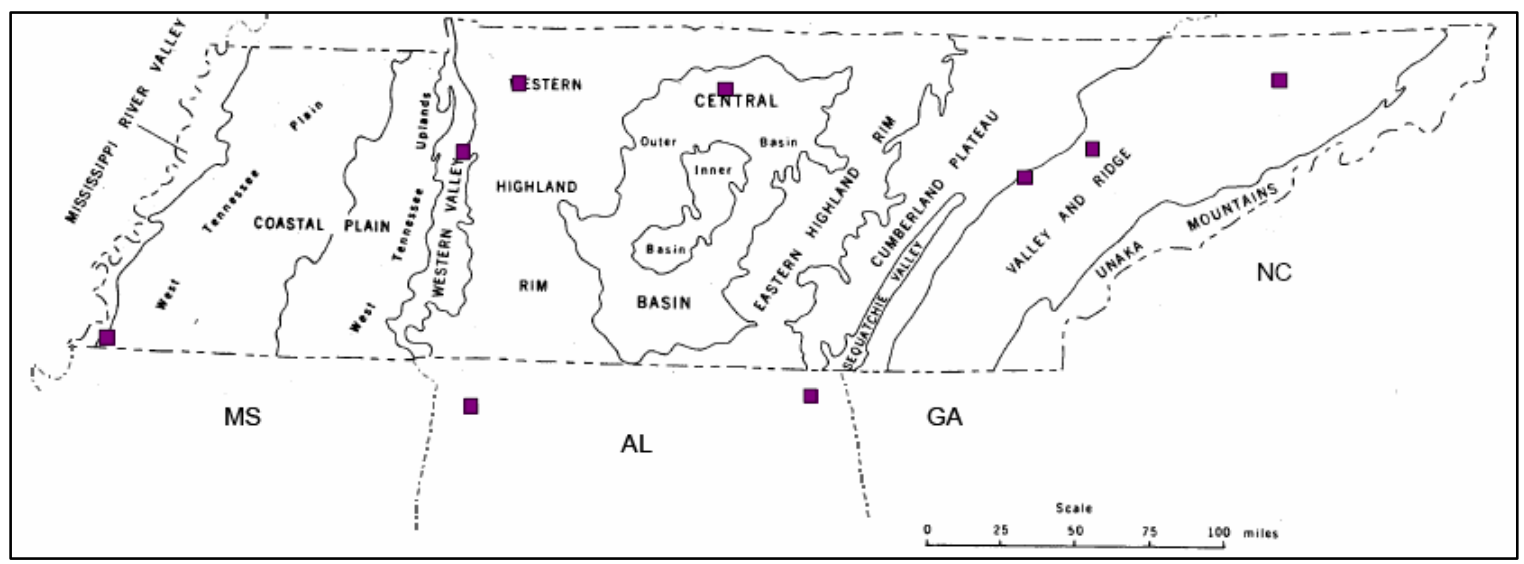

Fig. 14. Physiographic regions of Tennessee with locations of some TVA power plants (Tsouris et al. 2002).

Rock chemistry may significantly limit the potential use of both the Conasauga and lower Knox for sequestration. In Tennessee, the Knox Group consists almost entirely of carbonate rock, a rock type that could be dissolved in the carbonic acid formed by dissolution of $\mathrm{CO}_{2}$. The Conasauga Group also includes carbonate rocks. Before these units were used for sequestration, it would be necessary to investigate the lithologies of the injection zones and the overlying confining units to verify their physical integrity against dissolution.

Additionally, water quality and separation from overlying aquifers might limit the use of the Knox Group for sequestration, at least in some areas. Data on water quality in the lower Knox are available from several horizons within the same four wells that penetrate the basal sandstone; most water samples unaffected by deep-well waste injection had dissolved solids concentrations between 1,000 and 10,000 mg/L (Bradley 1986). These dissolved solids concentrations might disqualify these zones for use in $\mathrm{CO}_{2}$ sequestration (because the aquifer would be at least hypothetically suitable for use as a water supply, underground injection would be prohibited under current regulations). However, the dissolved solids concentration in the deepest samples from the Old Hickory well exceeded 10,000 $\mathrm{mg} / \mathrm{L}$, and under the eastern edge of the Eastern Highland Rim the upper Knox aquifer has dissolved solids concentrations exceeding 10,000 mg/L (Bradley 1986), so the lower Knox is likely to have sufficiently poor water quality for sequestration use in some parts of middle Tennessee.

\subsubsection{Knox Group in Eastern Kentucky and West Virginia}

The Knox Group is a regionally extensive stratigraphic unit that extends laterally into Kentucky, West Virginia, and Ohio, where MRCSP and Smyth et al. (2007) mapped potential sequestration capacity in this unit. There are, however, lateral changes in lithology within the Knox Group. Whereas the Knox Group in Tennessee consists almost entirely of dolomite (a carbonate rock), in some areas northeast of Tennessee the uppermost unit described within the Knox Group is 
the Rose Run Sandstone member, which consists of a stacked sequence of up to five sandstone units interbedded with thin layers of dolomite and shale (Riley et al. 2003). As a result of hydrocarbon production (primarily natural gas) and exploration in this unit, fairly extensive information is available on its properties. (However, not all sources agree on the characteristics and lateral extent of the Rose Run Sandstone. For example, Kipp 1997, does not mention the existence of a sandstone layer at the top of the Knox Group in central Kentucky. He states that the porosity and permeability associated with the unconformity at the upper surface of the Knox Group in that area are due to paleokarst development in carbonate rock units in the Knox.).

The Rose Run unit has sufficiently high porosity (average 9\%) and permeability (average $5 \mathrm{md}$ ) for carbon sequestration and is found at depths of several thousand feet (Riley et al. 2003). According to Riley et al., the overlying sequence of the Beekmantown dolomite, Wells Creek Formation, Black River Group, and Trenton/Lexington Limestone, which is up to 1,500 ft thick in Ohio, forms an effective confining layer above the Rose Run. Figure 15 shows elevation contours on the top of the Rose Run sandstone in Kentucky and Ohio; the formation is also believed to be present in West Virginia, which is outside the boundary of the mapped area. (Except for the center of the Cincinnati Arch, all elevation values are negative numbers that indicate elevations below sea level.) The upper surface of the Rose Run sandstone is a stratigraphic unconformity that reflects a period of erosion that occurred after its deposition. As a result of this erosion the thickness of this unit is highly variable (Fig. 16).

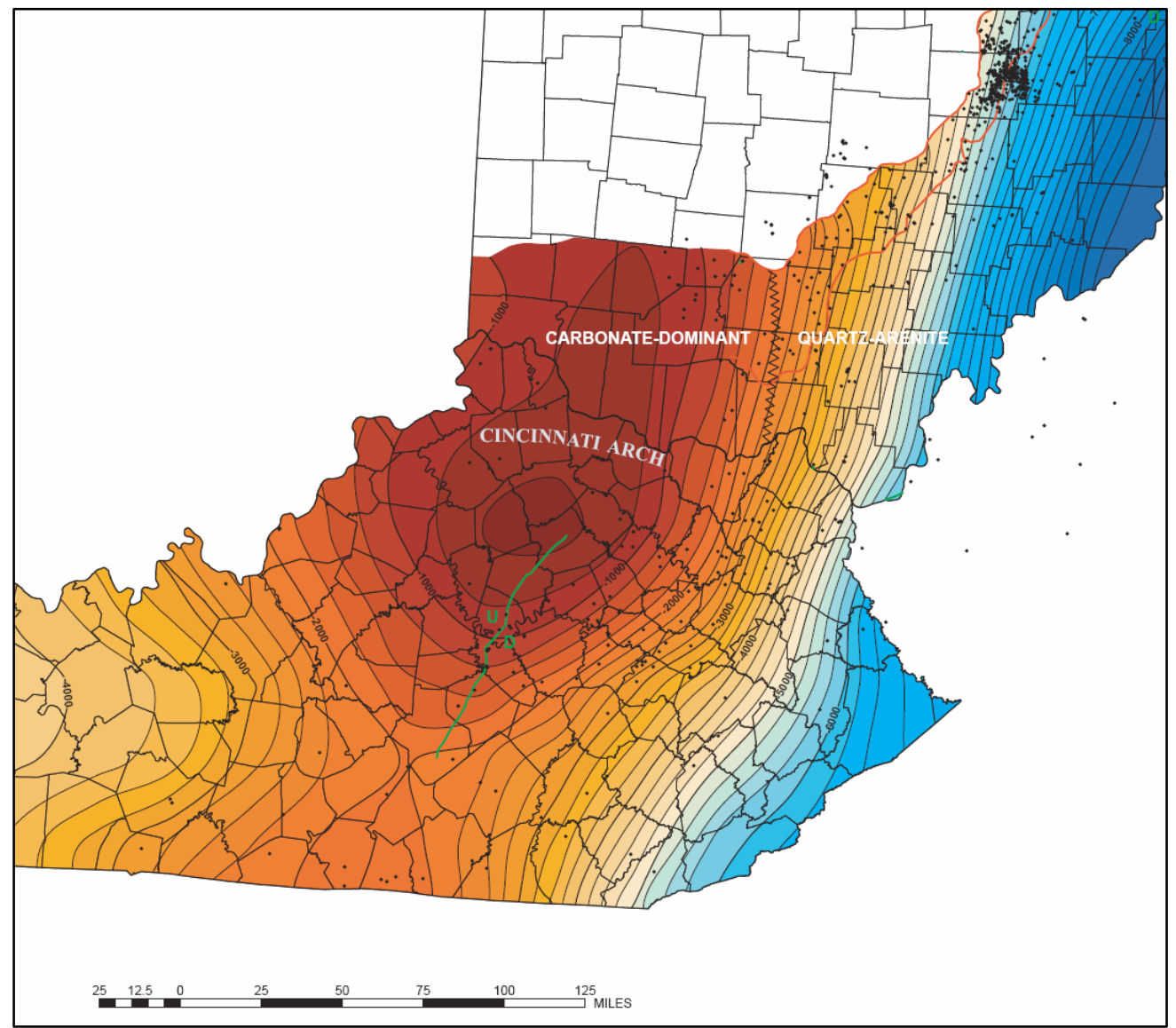

Fig. 15. Elevation contours on the top of the Rose Run Sandstone in parts of Kentucky and Ohio (modified from Riley et al. 2003). Except for the center of the Cincinnati Arch, all elevation values are negative numbers that indicate elevations below sea level. 
Smyth et al. (2007) treated the entire thickness of the Knox Group as potentially suitable for carbon sequestration (see Fig. 17) and estimated that the Knox Group in eastern Kentucky and southern Western Virginia has capacity for 30,000 million metric tons of $\mathrm{CO}_{2}$ (this is about $50 \%$ higher than SECARB's 19,700 million metric ton estimate of the capacity available in the Rose Run unit in a four-state region). Figure 17 shows depth contours to the top of the Knox Group and the total thickness of the unit, as reported by Smyth et al. (2007). As discussed in the Section 4.1.3.2, rock chemistry considerations might significantly limit the potential use of non-sandstone components of the Knox Group for sequestration.

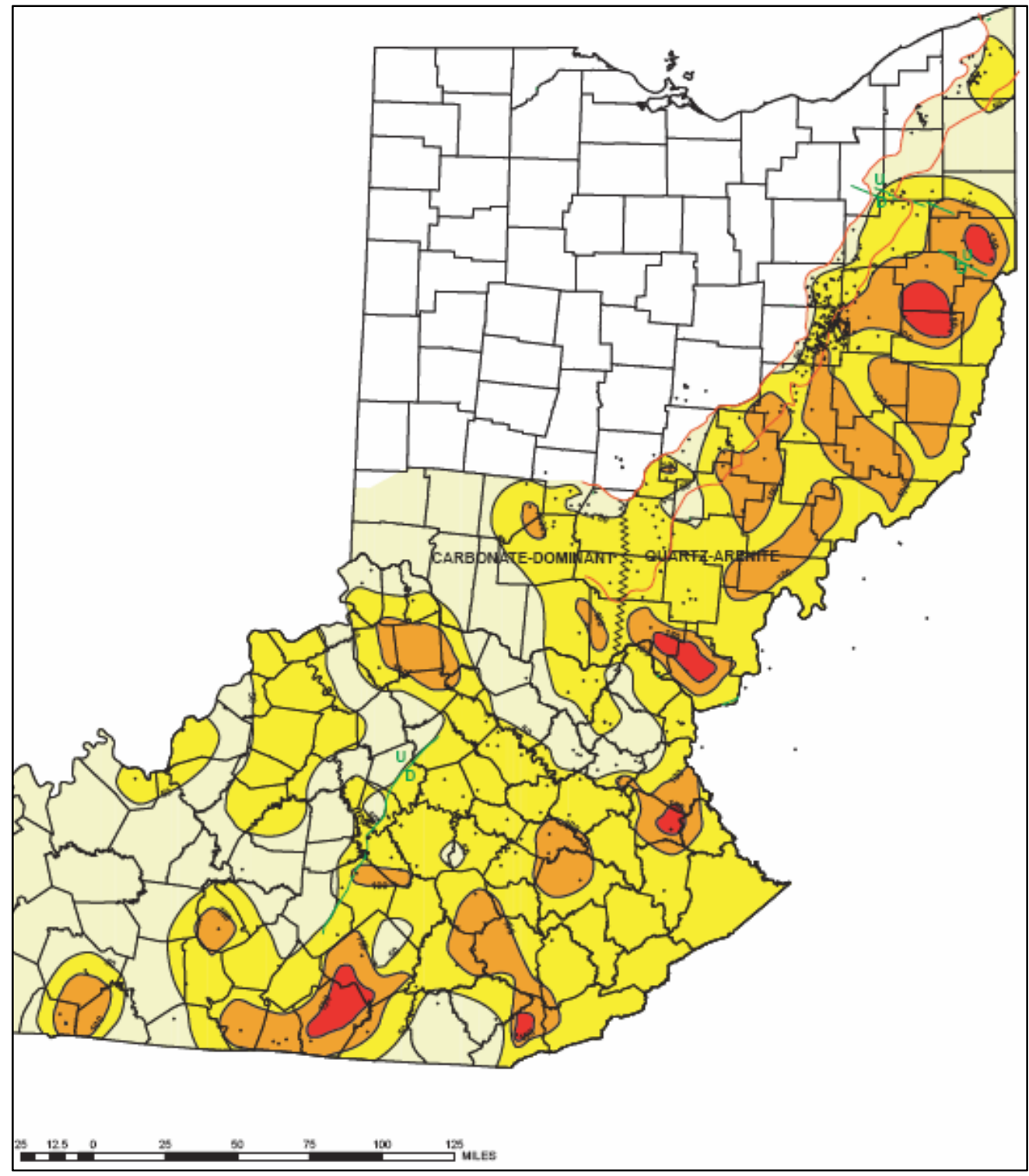

Fig. 16. Thickness of the Rose Run Sandstone in parts of Kentucky and Ohio (modified from Riley et al. 2003)

The depths reported for both the Rose Run Sandstone and the Knox Group in eastern Kentucky and southern West Virginia are sufficient to maintain supercritical $\mathrm{CO}_{2}$. 
In central Kentucky where the Knox Group is relatively near the land surface, the uppermost Knox Group forms an aquifer that can supply relatively fresh groundwater (dissolved solids less than $1,000 \mathrm{mg} / \mathrm{L}$ ) and is considered a potential source of water supply (Kipp 1997). However, concentrations of dissolved solids rise rapidly to the east, south, and west, to levels exceeding $10,000 \mathrm{mg} / \mathrm{L}$ (Kipp 1997). Therefore, in eastern Kentucky and southern West Virginia it is reasonable to expect that the Knox Group water chemistry would be unsuitable for water supply and suitable for sequestration.

The existence of commercial production of natural gas and oil from the Rose Run Sandstone creates potential for enhanced hydrocarbon production resulting from $\mathrm{CO}_{2}$ injection to help offset the costs of sequestration.

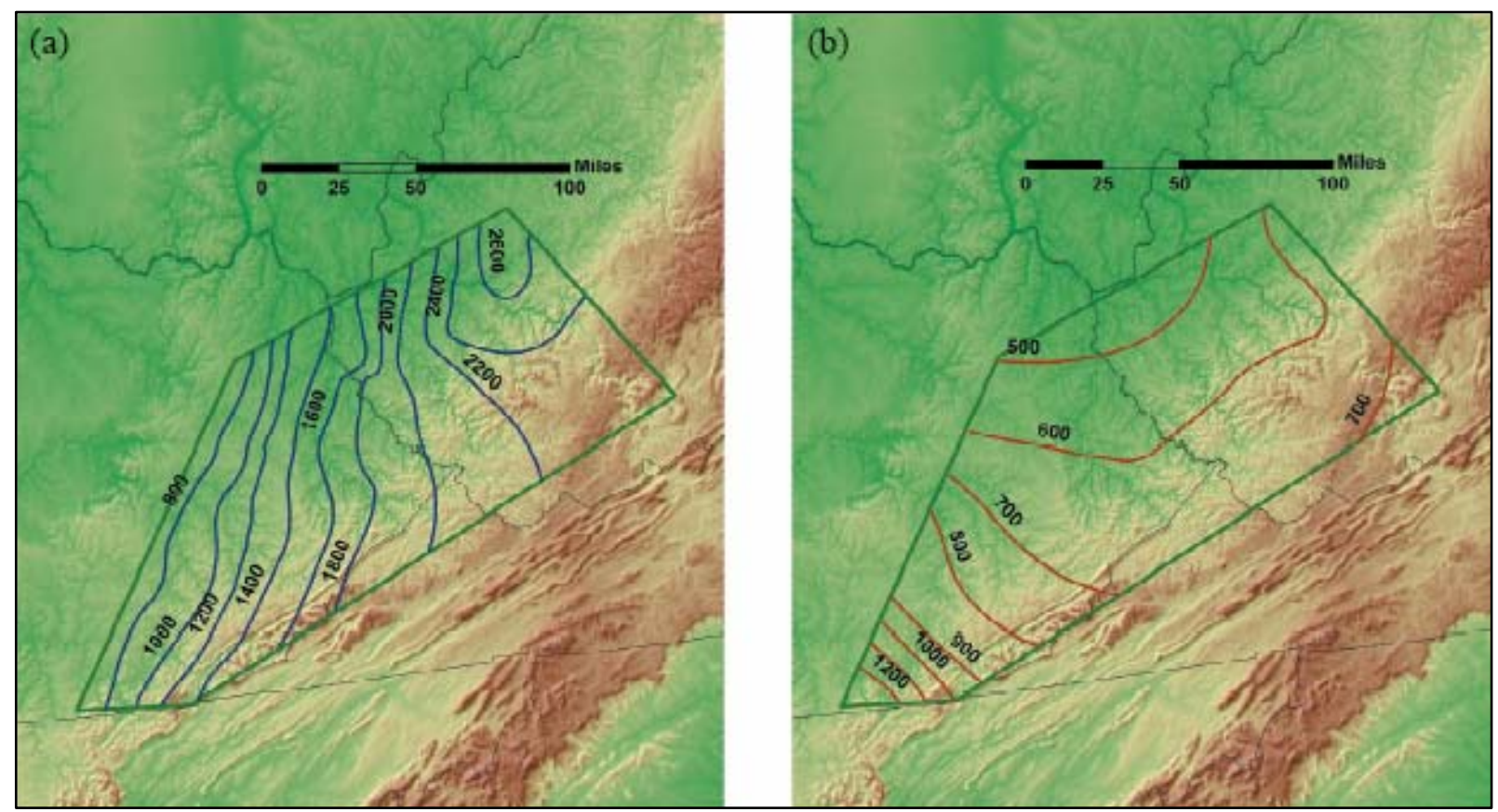

Fig. 17. Potential Knox Group geologic sink in eastern Kentucky, southern West Virginia, and southwestern Virginia as identified by Smyth et al. 2007: (a) depth (m) to top of Knox Group and (b) Knox Group thickness (m) (from Smyth et al. 2007).

\subsection{ECONOMIC COSTS OF CARBON SEQUESTRATION}

This section discusses existing information on the economic costs of geologic carbon sequestration. Estimates of the total cost of geologic sequestration typically divide the process into five components: capture, separation, transportation, storage, and monitoring. This discussion focuses on the costs of transportation, storage, and monitoring (rather than capture and separation) because the current assessment assumes the existence of a segregated $\mathrm{CO}_{2}$ stream suitable for sequestration.

The Tsouris et al. report provides some limited information about the costs of geologic sequestration. The report states that "an accepted cost estimate for onshore sequestration in an underground aquifer is $\$ 4.7 / \mathrm{mtC}$." This cost estimate includes a small amount of transport, preconditioning, and injection, but does not include the cost of investigating the site. The report states that in most cases, "a primary limiting economic condition would be the transport of $\mathrm{CO}_{2}$ from the 
plant to the disposal site" (Tsouris et al. 2002). The report did not consider long-distance transport because on-site injection was assumed.

A 2004 report published by Ecofys in The Netherlands also provides some estimates of the cost of $\mathrm{CO}_{2}$ transportation and storage. The report states that transport costs over $100 \mathrm{~km}(62 \mathrm{mi})$ range from $€ 1$ to $€ 6$ per ton $\mathrm{CO}_{2}$ [ $\$ 1.24$ to $\$ 7.46$ per ton $\mathrm{CO}_{2}$ in 2004 dollars (ECB 2007)]. The report adds that storage costs range from $€ 1$ to $€ 8$ per ton $\mathrm{CO}_{2}\left[\$ 1.24\right.$ to $\$ 9.95$ per ton $\mathrm{CO}_{2}$ in 2004 dollars (ECB 2007)] (Ecofys 2004).

Smyth et al. (2007) provides some recent estimates of the cost of $\mathrm{CO}_{2}$ transportation via pipeline in the southeastern United States. The report does not estimate the costs of $\mathrm{CO}_{2}$ capture/separation at the power plant or $\mathrm{CO}_{2}$ compression/injection at the storage site. For the five scenarios evaluated in the report, the cost of transporting $\mathrm{CO}_{2}$ via pipeline ranged from $\$ 3.56$ to $\$ 4.21$ per ton $\mathrm{CO}_{2}$ (Smyth et al. 2007).

The 2005 IPCC report provides the most detailed cost estimates for $\mathrm{CO}_{2}$ sequestration, but cautions that there is still:

"relatively little experience with the combination of $\mathrm{CO}_{2}$ capture, transport and storage in a fully integrated carbon dioxide capture and storage (CCS) system. And while some CCS components are already deployed in mature markets for certain industrial applications, CCS has still not been used in large-scale power plants (the application with most potential)" (IPCC 2005).

With this caveat, the 2005 IPCC report provides the cost estimates listed in Table 3 for transportation, storage, and monitoring and verification for geologic sequestration. The report cautions that the costs of these separate components cannot simply be summed to estimate the cost of the entire system.

Table 3. Estimated transportation, storage, and monitoring and verification costs for geologic sequestration

\begin{tabular}{|c|c|c|}
\hline Sequestration Component & $\begin{array}{c}\text { Cost Range } \\
\text { (U.S. \$) }\end{array}$ & Remarks \\
\hline Transportation & $\begin{array}{l}\$ 1-\$ 8 / \mathrm{tCO}_{2} \\
\text { transported }\end{array}$ & $\begin{array}{l}\text { Per } 250 \mathrm{~km}(155 \mathrm{mi}) \text { pipeline for mass flow } \\
\text { rates of } 5 \text { (high end) to } 40 \text { (low end) of } \mathrm{MtCO}_{2} \\
\text { per year. }\end{array}$ \\
\hline Geologic storage & $\begin{array}{c}\$ 0.5-\$ 8 / \mathrm{tCO}_{2} \\
\text { net injected }\end{array}$ & $\begin{array}{l}\text { Excluding potential revenues from enhanced oil } \\
\text { recovery (EOR) or enhanced coal bed methane } \\
\text { recovery. }\end{array}$ \\
\hline Monitoring and verification & $\begin{array}{c}\$ 0.1-\$ 0.3 / \mathrm{tCO}_{2} \\
\text { injected }\end{array}$ & $\begin{array}{l}\text { Includes pre-injection, injection, and post- } \\
\text { injection monitoring, and depends on } \\
\text { regulatory requirements. }\end{array}$ \\
\hline
\end{tabular}

Source: modified from IPCC 2005.

Based on the data in Table 3 and the current level of $\mathrm{CO}_{2}$ emissions from the John Sevier and Kingston power plants, Tables 4 and 5 provide estimates of the potential range of annual costs for $\mathrm{CO}_{2}$ transportation, storage, and monitoring and verification for the plants. As indicated by the estimates in Table 4, annual costs at the John Sevier plant could range from $\$ 8$ million to over $\$ 80$ million. The estimates in Table 5 indicate that annual costs at the Kingston plant could range from $\$ 17$ million to over $\$ 175$ million. These cost estimates exclude the cost of capture and separation. 
Also, it is likely that these cost estimates are low because they reflect current $\mathrm{CO}_{2}$ emissions and do not include the additional $\mathrm{CO}_{2}$ emissions that would be generated at each plant to meet the additional power requirements for capture and sequestration. However, these estimates offer some perspective on the relative scale of costs for transportation, storage, and monitoring and verification related to geologic sequestration.

The 2005 IPCC report also provides the estimates listed in Table 6 for the total cost of $\mathrm{CO}_{2}$ capture, transport, and geologic storage based on current technology for a pulverized coal power plant (the type of power plant at the John Sevier and Kingston sites). It is important to remember that the cost estimates in Table 6 are different than those in Tables 3 through 5 because Table 6 includes the cost of $\mathrm{CO}_{2}$ capture.

Table 4. Estimated annual transportation, storage, and monitoring and verification costs for geologic sequestration for the John Sevier power plant

\begin{tabular}{lcl}
\hline Sequestration Component & $\begin{array}{c}\text { Cost Range } \\
\text { (Million U.S. \$) }\end{array}$ & \multicolumn{1}{c}{ Remarks } \\
\hline Transportation & $\$ 5.1-\$ 40.8$ & $\begin{array}{l}\text { Per 250 km (155 mi) pipeline; 200 mi pipeline } \\
\text { would increase costs } \\
\text { Geologic storage }\end{array}$ \\
Monitoring and verification & $\$ 2.6-\$ 40.8$ & $\begin{array}{l}\text { Excluding potential revenues from EOR or } \\
\text { enhanced coal bed methane recovery. }\end{array}$ \\
& $\begin{array}{l}\text { Includes pre-injection, injection, and post- } \\
\text { injection monitoring, and depends on } \\
\text { regulatory requirements. }\end{array}$ \\
\hline
\end{tabular}

${ }^{a}$ Based on the plant's existing 5.1 million tons of $\mathrm{CO}_{2}$ emissions per year; does not reflect the additional $\mathrm{CO}_{2}$ emissions that would be generated to meet additional power requirements for capture and sequestration.

Source: based on Table 3 above; modified from IPCC 2005.

Table 5. Estimated annual transportation, storage, and monitoring and verification costs for geologic sequestration for the Kingston power plant

\begin{tabular}{lcl}
\hline Sequestration Component & $\begin{array}{c}\text { Cost Range } \\
\text { Million U.S. \$) }^{\text {a }}\end{array}$ & \multicolumn{1}{c}{ Remarks } \\
\hline Transportation & $\$ 11.0-\$ 88.0$ & $\begin{array}{l}\text { Per 250 km (155 mi) pipeline; 200 mi pipeline } \\
\text { would increase costs }\end{array}$ \\
Geologic storage & $\$ 5.5-\$ 88.0$ & $\begin{array}{l}\text { Excluding potential revenues from EOR or } \\
\text { enhanced coal bed methane recovery. }\end{array}$ \\
Monitoring and verification & $\$ 1.1-\$ 3.3$ & $\begin{array}{l}\text { Includes pre-injection, injection, and post- } \\
\text { injection monitoring, and depends on } \\
\text { regulatory requirements. }\end{array}$ \\
\hline
\end{tabular}

${ }^{a}$ Based on the plant's existing 11.0 million tons of $\mathrm{CO}_{2}$ emissions per year; does not reflect the additional $\mathrm{CO}_{2}$ emissions that would be generated to meet additional power requirements for capture and sequestration.

Source: based on Table 3 above; modified from IPCC 2005. 
Because the current assessment includes only the costs of $\mathrm{CO}_{2}$ transportation, storage, and monitoring (but not capture or separation), we have not generated tables similar to Table 6 for the John Sevier and Kingston plants. However, the data in Table 6 provide some perspective on the effect of total costs for $\mathrm{CO}_{2}$ geologic sequestration on the cost of power generation at a pulverized coal plant. As indicated in Table 6, the total costs for $\mathrm{CO}_{2}$ sequestration for a pulverized coal plant can increase the cost of electricity by between $43 \%$ and $91 \%$. For purposes of comparison, Ecofys estimates that for a pulverized coal plant the cost of $\mathrm{CO}_{2}$ sequestration would add $50 \%$ to the cost of electricity (Ecofys 2004). NETL's Carbon Sequestration Program estimates an even larger effect, with the cost of geologic sequestration adding at least $70 \%$ to $100 \%$ to the cost of electricity for pulverized coal plants (NETL 2007).

Table 6. Estimated total costs for $\mathrm{CO}_{2}$ capture and geologic sequestration at a pulverized coal power plant

\begin{tabular}{cc}
\hline \multicolumn{1}{c}{$\begin{array}{c}\text { Power Plant Performance } \\
\text { And Cost Parameters }\end{array}$} & $\begin{array}{c}\text { Cost Range } \\
\text { (U.S. } \$ \text { ) }\end{array}$ \\
\hline $\begin{array}{c}\text { Reference plant without } \mathbf{C O}_{2} \text { capture and storage } \\
\text { Cost of electricity }\end{array}$ & $\$ 0.043-\$ 0.052 / \mathrm{kWh}$ \\
Pulverized coal power plant with $\mathbf{C O}_{2}$ capture & $24-40 \%$ \\
Increased fuel requirement & $0.82-0.97 \mathrm{~kg} / \mathrm{kWh}$ \\
$\mathrm{CO}_{2}$ captured & $0.62-0.70 \mathrm{~kg} / \mathrm{kWh}$ \\
$\mathrm{CO}_{2}$ avoided & $81-88 \%$ \\
Percent $\mathrm{CO}_{2}$ avoided & \\
Pulverized coal power plant with $\mathbf{C O}_{2}$ capture and & \\
geologic storage & $\$ 0.063-\$ 0.099 / \mathrm{kWh}$ \\
Cost of electricity & $\$ 0.019-\$ 0.047 / \mathrm{kWh}$ \\
Cost of capture and storage & $43-91 \%$ \\
Percent increase in cost of electricity & $\$ 30-\$ 71 / \mathrm{tCO} 2$ avoided \\
Mitigation cost: $\mathrm{tCO}$ avoided & $\$ 110-\$ 260 / \mathrm{tC}$ avoided \\
\hline Mitigation cost: $\mathrm{tC}$ avoided
\end{tabular}

Source: modified from IPCC 2005.

The 2005 IPCC report states that for pulverized coal plants with geological storage and no EOR credit, the total cost of $\mathrm{CO}_{2}$ capture and geologic sequestration ranges from $\$ 0.02$ to $\$ 0.05$ per $\mathrm{kWh}$. The report adds that this cost can be reduced by about $\$ 0.01$ to $\$ 0.02$ per $\mathrm{kWh}$ when using EOR with $\mathrm{CO}_{2}$ storage because the EOR revenues partly compensate for the total costs (IPCC 2005).

Finally, the 2005 IPCC report states that for $\mathrm{CO}_{2}$ capture and storage systems to be deployed in the power sector the price of $\mathrm{CO}_{2}$ reductions would have to exceed $\$ 25$ to $\$ 30$ per ton of $\mathrm{CO}_{2}$, or an equivalent limit on $\mathrm{CO}_{2}$ emissions would have to be mandated. The report adds that in the absence of mandated measures for limiting $\mathrm{CO}_{2}$ emissions, there are only small, niche opportunities for $\mathrm{CO}_{2}$ capture and storage systems to be deployed. The report concludes that these early opportunities involve: (1) $\mathrm{CO}_{2}$ captured from a high-purity, low-cost source; (2) the transport of $\mathrm{CO}_{2}$ over distances of less than $50 \mathrm{~km}(31 \mathrm{mi})$; and (3) $\mathrm{CO}_{2}$ storage in a value-added application such as EOR (IPCC 2005). 


\section{CONCLUSIONS}

The purpose of this assessment is to make a "first cut" determination of whether there is sufficient potential for geologic carbon sequestration within 200 miles of TVA's John Sevier and Kingston power plants for TVA and ORNL to proceed with a joint proposal for a larger project with a strong carbon management element. The information reviewed for this report indicates that geologic carbon sequestration is likely to be feasible at several locations within a reasonable transportation distance of both power plants. Therefore, it is possible that TVA and ORNL could proceed with a joint proposal for a larger project at one of the plants. As discussed in Section 4.2, the largest impediment to geologic sequestration at either of the plants is likely to be the economic cost of capturing, separating, transporting, storing, and monitoring the $\mathrm{CO}_{2}$.

The sequestration target area with the best near-term prospects for successful utilization appears to be the Pocahontas Basin in southwestern Virginia. Ongoing coal bed methane production activity in that area provides some of the needed data and infrastructure, enhanced production of natural gas resulting from $\mathrm{CO}_{2}$ injection could help offset the costs of sequestration, and experience gained from the small-scale demonstration of sequestration being conducted for Phase 2 of the DOE Carbon Sequestration Program would aid in implementing large-scale sequestration. Further, the existence of an extensive network of natural gas pipelines in the Pocahontas Basin area (Nemeth 2006) could somewhat reduce the cost of sequestration, not only by reducing infrastructure costs for future natural gas recovery, but also by reducing costs for right-of-way acquisition and development for $\mathrm{CO}_{2}$ pipelines.

Distance from the John Sevier power plant (about 100 miles) makes the Pocahontas Basin in southwestern Virginia a logical location for sequestering captured carbon from that facility. The estimated sequestration capacity in Buchanan and Dickenson counties (308 to 818 million metric tons) corresponds to about 65 to 175 years of $\mathrm{CO}_{2}$ emissions from the John Sevier plant. However, because this area is near multiple $\mathrm{CO}_{2}$ sources (for example, Fig. 6 indicates the locations of two power plants close to the Pocahontas Basin; also, the Eastman Chemical plant in Kingsport, Tennessee, is another potential customer for this area's sequestration capacity) and because of the factors that make it relatively attractive for near-term geologic sequestration, once the Pocahontas Basin is developed for sequestration its capacity is likely to be utilized more quickly than these numbers suggest. However, once sequestration is successfully deployed in the Pocahontas Basin, it is likely to expand to other coal-resource areas in the region.

The potential capacity for coal bed sequestration of $\mathrm{CO}_{2}$ in the region is small relative to the large potential $\mathrm{CO}_{2}$ sequestration capacity estimated to be present in deep saline formations below middle Tennessee, eastern Kentucky, and southern West Virginia, at distances within 200 miles or less of the two power plants. However, due to sparse and inconsistent information on the prospective sequestration reservoirs in these areas, they are not judged to be good near-term candidates for sequestration projects. Additional investigation is needed in these areas (including drilling of test wells) before they can be seriously considered for $\mathrm{CO}_{2}$ sequestration. 


\section{LIST OF PREPARERS}

Ellen D. Smith, B.A., Geology, Carleton College, M.S. Water Resources Management, University of Wisconsin-Madison

James W. Saulsbury, B.A., History, University of Tennessee, M.S., Planning, University of Tennessee 


\section{REFERENCES}

Battelle. 2005. The Midwest Regional Carbon Sequestration Partnership (MRCSP) Phase 1 Final Report. December. http://198.87.0.58/PhaseIReport.aspx

Bradley, M. W. 1986. Preliminary Evaluation of the Knox Group in Tennessee for Receiving Injected Wastes. U.S. Geological Survey, Water Resource Investigations Report 85-4304. http://pubs.usgs.gov/wri/wri85-4304/pdf/wrir_85-4304_a.pdf

Conrad, J. M., M. J. Miller, J. Phillips, and N. Ripepi. 2006 Characterization of Central Appalachian Basin CBM Development: Potential for Carbon Sequestration and Enhanced CBM Recovery, Proceedings. 2006 International Coalbed Methane Symposium, Preprint 0625. May 22-26, 2006, Tuscaloosa, AL. http://www.energy.vt.edu/Publications/2006_CBM_Conrad.pdf

DOE (U.S. Department of Energy). 2006. Carbon Sequestration Atlas of the United States and Canada. Office of Fossil Energy, National Energy Technology Laboratory. www.netl.doe.gov/publications/carbon_seq/atlas/index.html

ECB (European Central Bank). 2007. Statistical Data Storehouse: Historic Exchange Rates. http://sdw.ecb.europa.eu/browse.do

Ecofys. 2004. Global Carbon Dioxide Storage Potential and Capture Costs. http://www.ecofys.com/com/publications/documents/GlobalCarbonDioxideStorage.pdf

EPA (U.S. Environmental Protection Agency). 2004. The Central Appalachian Coal Basin, Attachment 6 in: Evaluation of Impacts to Underground Sources of Drinking Water by Hydraulic Fracturing of Coalbed Methane Reservoirs. EPA 816-R-04-003. http://www.epa.gov/safewater/uic/cbmstudy/pdfs/completestudy/attachment 06_6-4-04.pdf

IPCC (Intergovernmental Panel on Climate Change). 2005. Special Report on Carbon Dioxide Capture and Storage. http://www.ipcc.ch/activity/srccs/index.htm

Kipp, J. A. 1997. Fresh-Water Aquifer in the Knox Group (Cambrian-Ordovician) of Central Kentucky. Report of Investigations 12, Series XI, University of Kentucky, Kentucky Geological Survey. http://www.uky.edu/KGS/pdf/ri11_12.pdf

MIDCARB (Midcontinent Interactive Digital Carbon Atlas and Relational dataBase). 2007. http://www.midcarb.org/ (accessed September 13, 2007).

Milici, R. C. and J. R. Hatch. 2004. Assessment of Undiscovered Carboniferous Coal-Bed Gas Resources of the Appalachian Basin and Black Warrior Basin Provinces, 2002. U.S. Geological Survey Fact Sheet 2004-3092. September.

Mulderink, D. and M. W. Bradley. 1986. Preliminary Evaluation of the Basal Sandstone in Tennessee for Receiving Injected Wastes. U.S. Geological Survey, Water Resource Investigations Report 85-4303. http://pubs.usgs.gov/wri/wri85-4303/pdf/wrir_85-4303 a.pdf

Nemeth, K. J. 2006. Southeast Regional Carbon Sequestration Partnership (SECARB) Draft Final Report. Southern States Energy Board, Norcross, GA. November 1. http://www.osti.gov/bridge/servlets/purl/909272-YKPAtG/909272.PDF 
NETL (National Energy Technology Laboratory). 2007. Carbon Sequestration: Frequently Asked Questions. http://www.netl.doe.gov/technologies/carbon_seq/faqs.html

Riley, R. A., M. T. Baranoski, J. B. Hickman, and D. M. Powers. 2003. Rose Run Structure and Isopach Map of Ohio and Kentucky. http://www.midcarb.org/Documents/AAPG-Eastern$\underline{\text { 2003/Rose Run.pdf }}$

SECARB (Southeast Regional Carbon Sequestration Partnership). 2005. Identification of the Most Promising Capture, Sequestration, and Transport Options and Preparation of Action Plans for the SECARB Geographic Region. Semiannual Technical Report. September 30.

Smyth, R. C., S. D. Hovorka, T. Meckel, C. Breton, J. G. Paine, G. R. Hill et al. 2007. Potential Sinks for Geologic Storage of Carbon Dioxide Generated in the Carolinas. Gulf Coast Carbon Center, Bureau of Economic Geology, Jackson School of Geosciences, The University of Texas at Austin. http://www.beg.utexas.edu/environqlty/co2seq/pubs_presentations/CarolinasSummary 16Apr i107.pdf

Tennessee Division of Geology. undated. Generalized Geologic Map of Tennessee. http://www.tennessee.gov/environment/tdg/bigmap.shtml

Tsouris, C., G. Moline, and D. Aaron. 2002. Separation of $\mathrm{CO}_{2}$ from Flue Gas and Potential for Geologic Sequestration. Oak Ridge National Laboratory, Oak Ridge, Tennessee.

TVA (Tennessee Valley Authority). 2007a. John Sevier Fossil Plant. www.tva.com/sites/johnsevier.htm

TVA. 2007b. Kingston Fossil Plant. www.tva.com/sites/kingston.htm

Virginia Center for Coal and Energy Research. 2007. SECARB Coal Group. http://www.energy.vt.edu/secarb/ (accessed August 23, 2007). 